\title{
Piotr Borowski
}

Uniwersytet w Białymstoku e-mail: borpio5@wp.pl

\section{Przyczyny uchwalenia ustawy o Rezerwie Federalnej z 23 grudnia 1913 roku. Powstanie banku centralnego Stanów Zjednoczonych Ameryki}

\author{
SUMMARY \\ The Reasons of Passing the Federal Reserve Act \\ of 23 December 1913. The Formation of Central Bank of the USA
}

The Federal Reserve System, often called the Fed, is the central bank of the United States. The establishment of the Federal Reserve System in 1913 is conventionally viewed as the inevitable outcome of the turmoil surrounding the Panic of 1907. The Panic of 1907 was the last and most severe of the bank panics that plagued the pre-Civil War Era and the National Banking Era of the United States. Federal regulation was absent in the antebellum period with panics in 1819, 1837, and 1857. During the National Banking Era, banking panics occurred in 1873, 1884, 1890, 1893 , and 1907. Bank panics were characterized by the widespread appearance of ban runs, attempts by depositors to simultaneously withdraw their deposits from the banking system. Because banks did not (and still do not) keep a 100\% reserve against deposit, it paid to be near the front of the line of depositors demanding their money when a panic blew up. What sets the 1907 panic apart from earlier panics was that the crisis focused on the trust companies in New York City. The National Banking Era lasted from 1863 to 1914, when Congress, in part to eliminate these recurring panics, after considerable debate, created the Federal Reserve System. Another congressional objective was to provide an institution that could centralize the clearing of payments across the nation. Congress also desired the government to have a central depository for its funds. The Fed's principal goal of economic stability has not changed since its creation in 1913.

Key words: Federal Reserve System, financial stability, National Banking System, banking panics, the Panic of 1907, prelude to the Federal Reserve, National Monetary Commission, Federal Reserve Act 
1. Historia bankowości centralnej Stanów Zjednoczonych Ameryki jest nierozerwalnie związana $\mathrm{z}$ najważniejszymi wydarzeniami politycznymi tego kraju. Począwszy od przyznania prywatnemu przedsiębiorcy Robertowi Morrisowi przez Kongres Kontynentalny (Continental Congress) w 1781 r. licencji (charter) na otworzenie w Filadelfii Banku Północnej Ameryki (the Bank of North America), a następnie powołanie, także w Filadelfii, odpowiednio w 1791 i 1816 r., ustawą federalną Pierwszego i Drugiego Banku Stanów Zjednoczonych (the First and the Second Bank of the United States), ustawą o pieniądzu narodowym (National Currency Act) z 1863 r. zdecentralizowanego systemu bankowości centralnej (National Banking System), a wreszcie ustanowienie w 1913 r. Systemu Rezerwy Federalnej (Federal Reserve System), głównym celem tych instytucji było zapewnienie sfinansowania wydatków wojennych Departamentu Skarbu oraz sprawna obsługa długu publicznego ${ }^{1}$. Prawodawcy chodziło zatem przede wszystkim o utrzymanie stabilności finansowej i wzrostu gospodarczego w warunkach luźnej polityki fiskalnej i wzrastających deficytów budżetowych albo niedopuszczenie do wystąpienia deflacyjnej recesji spowodowanej upadłością nawet jednej instytucji finansowej² ${ }^{2}$ Pozostałe wyznaczniki działalności operacyjnej banku centralnego w postaci zapewnienia pełnego zatrudnienia, stabilnego poziomu cen (rozumianej jako dopuszczenie występowania pełzającej inflacji rzędu nawet 2-3\%) oraz umiarkowanej długoterminowej stopy procentowej, które to zostały nałożone na System Rezerwy Federalnej dopiero na podstawie ustawy o pełnym zatrudnieniu i zrównoważonym rozwoju (the Full Employment and Balanced Growth Act) z 1978 r., nie miały żadnego znaczenia, ponieważ aż do zakończenia wielkiego kryzysu w 1933 r. w ogóle nie uświadamiano sobie istnienia polityki pieniężnej jako zasadniczego - wespół z polityką budżetową - segmentu publicznej polityki gospodarczej ${ }^{3}$. Innymi słowy, dążenie do osiągnięcia określonych makroekonomicznych przesłanek działalności banku centralnego za pomocą instrumentów polityki pieniężnej, służących refinansowaniu działalności kredytowej banków handlowych, stało się prawnie dopuszczalne dopiero $\mathrm{z}$ chwilą wejścia $\mathrm{w}$ życie ustawy o zatrudnieniu

1 Por. np. R. LeRoy Miller, D. D. van Hoose, Essentials of Money, Banking, and Financial Markets, Addison-Wesley Longman, Inc., New York 1997, s. 295-306.

2 Por. R. G. Hubbard, Money, the Financial System and the Economy, Addison-Wesley Longman, Inc., New York 1997, s. 483; P. Trescott, Central Banking, [w:] Encyclopedia of American Economic History. Studies of the Principal Movement and Ideas, ed. G. Porter, vol. 2, Charles Scribner's Sons, New York 1980, s. 737-744.

3 Por. J. Głuchowski: Polityka fiskalno-monetarna Stanów Zjednoczonych Ameryki, Państwowe Wydawnictwo Naukowe, Torun 1979, s. 26. 
(Employment Act), co nastąpiło 20 lutego 1946 r. Ustawa ta zalegalizowała bowiem występowanie deficytu budżetowego, który jest finansowany przez oferowanie do sprzedaży federalnych papierów wartościowych ${ }^{4}$. Stanowią one zasadniczą część kapitału rezerwowego wszystkich instytucji depozytowych działających na terenie Stanów Zjednoczonych oraz zagranicznych banków centralnych i handlowych, które zamieniają omawiane papiery wartościowe na dolary amerykańskie, przedstawiając do redyskonta w Regionalnym Banku Rezerwy Federalnej ${ }^{5}$. $\mathrm{W}$ ten sposób instytucje finansowe odzyskują nie tylko zainwestowane w bony i obligacje skarbowe fundusze własne, ale również wynagrodzenie w postaci ustalonego w momencie zawierania transakcji procentu. Dzięki temu odzyskują środki, które mogą ponownie przeznaczyć na zakup rządowych papierów wartościowych, zainwestować w walory giełdowe albo wykorzystać na udzielenie kredytu ${ }^{6}$. Korzyść odnoszą zarazem władze monetarne: zaopatrzenie jednostek organizacyjnych sektora bankowego w pieniądze i kredyt ma stymulować inwestycje w sferę gospodarki realnej, charakteryzujące się najwyższą stopą zwrotu, a to pozwala oczekiwać wsparcia realizacji celów ogólnogospodarczych ${ }^{7}$.

Refinansowanie działalności kredytowej banków handlowych, przejawiające się zasygnalizowaną wyżej zamianą pieniądza bankowego (wkłady na rachunkach instytucji depozytowych, pieniądz bezgotówkowy) na pieniądz banku centralnego (fizycznie istniejące banknoty i monety), należy do podstawowych zadań każdego banku centralnego, ponieważ chroni banki przed niewypłacalnością, stanowiąc tym samym rynek rezerw kasowych systemu bankowego i gospodarki finansowej państwa, a w rezultacie umożliwiając władzom monetarnym decydowanie o płynności rynku pieniężnego. Podkreślić przy tym trzeba, iż sprawne wywiązywanie się z tego zadania wynika z przyznania współczesnym bankom centralnym, w tym także i Systemowi Rezerwy Federalnej, przywileju tworzenia fizycznie istniejącego pieniądza. Funkcja emisji pieniądza, będącego powszechnym ekwiwalentem, środkiem obiegu, miernikiem wartości oraz środkiem ostatecznej zapłaty, jest konieczna do podtrzymania płynności nie tylko każdego banku, ale przede wszystkim całego sektora bankowego, ponieważ dyskontowanie papierów wartościowych $\mathrm{z}$ reguły generuje straty finansowe. Toteż w praktyce bank centralny występuje na rynku pieniężnym jako pożyczkodawca

4 Por. J. P. Judd, G. D. Rudebusch, The Goals of U.S. Monetary Policy, tekst zaczerpnięty został z oficjalnej strony internetowej Regionalnego Banku Rezerwy Federalnej w San Francisco, dostępnej pod adresem: http://www.frbsf.org/econrsrch/wklyltr99/el99-04.html, s. 1-2.

5 Por. P. A. Samuelson, W. D. Nordhaus, Ekonomia. Tom 2, Wydawnictwo Naukowe PWN, Warszawa 2008, s. 192-197.

6 Por. np. W. Baka, Pieniądz, bank centralny i polityka pieniężna, [w:] Ekonomia dla prawników i nie tylko, red. M. Bednarski, J. Wilkin, Wydawnictwo Prawnicze LexisNexis, Warszawa 2003, s. 356-359 .

7 M. Iwanicz-Drozdowska, W. L. Jaworski, Z. Zawadzka, Bankowość. Zagadnienia podstawowe, Wydawnictwo Poltext, Warszawa 2010, s. 67-68. 
ostatniej instancji (lender of last resort), który jest ostatecznym źródłem centralnego pieniądza rezerwowego ${ }^{8}$.

Powierzenie Systemowi Rezerwy Federalnej prawa podmiotowego Kongresu do bicia pieniądza i określania jego wartości, wyrażonego w artykule I sekcja 8 punkt 5 Konstytucji Stanów Zjednoczonych (Constitution of the United States $)^{9}$, który począwszy od 15 sierpnia 1971 r. jest pieniądzem fiducjarnym (niewymienialnym na pieniądz kruszcowy), nie może oznaczać braku jakichkolwiek reguł, czy wręcz automatyzmu, jeśli chodzi o udzielanie wsparcia płynnościowego instytucjonalnym uczestnikom rynku finansowego, zagrożonym niewypłacalnością. Przeciwnie, głównym celem polityki pieniężnej Systemu Rezerwy Federalnej, wynikającym $\mathrm{z}$ artykułu 2A ustawy tworzącej ten podmiot prawnofinansowy, jest wciąż zapewnienie stabilności cen, a zatem niedopuszczenie do pojawienia się inflacji, a to stoi w sprzeczności z rolą pożyczkodawcy ostatniej instancji. Innymi słowy, wzrost inflacji i obawy przed potencjalnym przegrzaniem koniunktury mogą spowodować podniesienie stóp procentowych banku centralnego, i to mimo że podstawowym uwarunkowaniem jego działalności jest niedopuszczenie do wystąpienia dużej ogólnej depresji gospodarczej w Stanach Zjednoczonych ${ }^{10}$. Problem polega na tym, że upadłość jednej instytucji finansowej może pociągnąć za sobą niewypłacalność i upadłość innych, co w krótkim czasie może doprowadzić do pojawienia się paniki bankowej i kryzysu finansowego. Implikacje braku stabilności w sektorze finansowym mogą w konsekwencji rozprzestrzenić się na sferę gospodarki realnej i wywołać masowy wzrost bezrobocia, związane z tym spowolnienie gospodarcze, a nawet recesję. Wysoka cena, jaką musi płacić całe społeczeństwo za kryzys w systemie finansowym skłania do podejmowania działań służących ochronie tego systemu. Wielu ekspertów, a wśród nich były prezes Fed, Paul Volcker, zwraca ponadto uwagę, że pierwotnym celem Systemu Rezerwy Federalnej miało być zapewnienie stabilności systemu finansowego poprzez wypełnianie roli pożyczkodawcy ostatniej instancji i w ten sposób zapobieganie występowaniu kryzysów finansowych ${ }^{11}$. Bank centralny nie może się jednak ograniczać do wspierania płynności poszczególnych instytucji depozytowych. Dąży on przede wszystkim do

8 M. Iwanicz-Drozdowska, W. L. Jaworski, Z. Zawadzka, op. cit., s. 82; M. Zdebel, System pieniężny, dewizowy i bankowy, [w:] Finanse publiczne i prawo finansowe, red. C. Kosikowski, E. Ruśkowski, Dom Wydawniczy ABC, Warszawa 2003, s. 197-199.

9 Tekst współcześnie obowiązującej Konstytucji Stanów Zjednoczonych Ameryki (Constitution of the United States) został zaczerpnięty ze strony internetowej MacMillan Law Library. Electronic Reference Desk, dostępnej pod adresem: http://www.law.emory.edu?FEDERAL/usconst.html, s. 8.

10 Por. S. Gomułka, Wplyw zaburzeń na międzynarodowych rynkach finansowych na sytuację gospodarcza Polski: komentarz makroekonomisty, „Bank i Kredyt”, sierpień - wrzesień 2007, s. 23.

11 Por. O. Szczepańska, P. Sotomska-Krzysztofik, M. Pawliszyn, A. Pawlikowski, Instytucjonalne uwarunkowania stabilności finansowej na przykładzie wybranych krajów, Narodowy Bank Polski, Departament Komunikacji Społecznej, Materiały i Studia, Zeszyt nr 173, Warszawa 2004, s. 9 i 57. 
zapobieżenia zjawiskom kryzysowym, które by zagroziły bezpieczeństwu całego systemu bankowego. Jest to możliwe dzięki wypełnianiu zadań należących do istoty nadzoru bankowego ${ }^{12}$.

2. Ustawa o Rezerwie Federalnej (the Federal Reserve Act), uchwalona 23 grudnia 1913 r. i tego samego dnia podpisana przez prezydenta Thomasa Woodrowa Wilsona, powołała do życia istniejący do dnia dzisiejszego bank centralny Stanów Zjednoczonych, czyli System Rezerwy Federalnej, w Polsce nazywany również Urzędem Rezerwy Federalnej, Rezerwą Federalną lub oznaczany skrótem SRF (Federal Reserve System; w Stanach Zjednoczonych określany też jako Federal Reserve, a w powszechnie stosowanym skrócie jako Fed). Instytucja ta została zatem utworzona znacznie później niż banki centralne takich krajów, jak Szwecja (Riksbank, utworzony w 1668 r.), Wielka Brytania (Bank of England, ustanowiony w 1694 r.), czy Francja (Banque de France, założony w roku 1800). Bank centralny Stanów Zjednoczonych jest jednak starszy niż np. bank centralny Kanady (Bank of Canada, 1935) ${ }^{13}$.

3. Głównym powodem powołania Systemu Rezerwy Federalnej, złożonego z dwunastu federalnych banków emisyjnych wraz z naczelnym ich organem, Radą Rezerwy Federalnej (na mocy ustawy Prawo bankowe z 1935 r. przekształconej w Radę Gubernatorów Rezerwy Federalnej), była potrzeba stworzenia elastycznego pieniądza oraz mechanizmu dyskontowania weksli bankowych $i$ handlowych, ujednolicenia narodowej waluty, usprawnienia nadzoru nad bankami komercyjnymi, przeciwdziałania procesom inflacyjnym i deflacyjnym, a także stworzenie warunków sprzyjających stałości siły nabywczej pieniądza, wysokiemu zatrudnieniu oraz stabilnemu wzrostowi gospodarczemu. Konieczność uporządkowania systemu bankowego i nadania mu właściwej organizacji, odpowiadającej potrzebom rozwijającej się w szybkim tempie gospodarki amerykańskiej, wynikała również z tego, że obok Departamentu Skarbu uprawnionego do emisji pieniądza federalnego, do chwili rozpoczęcia działalności przez Fed, co nastąpiło 16 listopada 1914 r., wszystkie banki handlowe na terytorium Stanów Zjednoczonych mogły emitować własne banknoty, a to dodatkowo pogłębiało chaos panujący na rynku finansowym i wywoływało częste zaburzenia obiegu pieniężnego. W rezultacie dopiero ustawa o Rezerwie Federalnej z 1913 r. zapewniła możność dostosowania obiegu pieniężnego do potrzeb gospodarczych. Definitywna delegalizacja i zastąpienie ponad 30 tysięcy (!) prywatnych biletów bankowych oraz innych środków obiegu (emisją własnego

12 M. Iwanicz-Drozdowska, W. L. Jaworski, Z. Zawadzka, op. cit., s. 41-42.

13 Por. L. Oręziak, System Rezerwy Federalnej jako bank centralny Stanów Zjednoczonych, [w:] Bankowość centralna od A do Z, red. R. Kokoszczyński, B. Pietrzak, Narodowy Bank Polski, Departament Komunikacji Społecznej, Warszawa 2008, s. 210. 
pieniądza zajmowały się także m.in. apteki oraz inne zakłady pracy) przez jednolite banknoty Rezerwy Federalnej (the Federal Reserve Notes) miała z kolei przyczynić się do bardziej swobodnego regulowania krajowej podaży pieniądza i warunków kredytowania przez federalne władze monetarne $\mathrm{w}$ taki sposób, aby doprowadzić do wygładzenia koniunkturalnych wahań dochodu i zatrudnienia oraz zachować integralność krajowych instytucji finansowych. Chodziło bowiem o to, aby stworzyć sprawny mechanizm pozwalający na większy przyrost podaży pieniądza w okresie kryzysu finansowego lub recesji, a więc w sytuacji, kiedy banki i inne instytucje finansowe najbardziej potrzebowały zasilania z zewnątrz i były zmuszone ograniczać lub wręcz zaprzestawać dokonywania ekspansji pieniężnej. Krótko mówiąc, nowy federalny bank centralny był nade wszystko potrzebny do zapewnienia elastycznej podaży pieniądza ${ }^{14}$. Poza tym na System Rezerwy Federalnej nałożono odpowiedzialność za stabilizację wartości pieniądza oraz finansowanie rozwoju gospodarczego kraju ${ }^{15}$.

Ustanowienie banku centralnego wymuszał również system waluty złotej, który został przyjęty w Stanach Zjednoczonych na podstawie ustawy o standardzie złota (the Gold Standard Act) uchwalonej 14 marca 1900 r., choć faktycznie zaadaptowano go już w 1873 r. W systemie waluty złotej państwo za pośrednictwem banku centralnego zobowiązało się wykupić znajdującą się w obiegu i na rachunkach banków komercyjnych, emitowaną przez siebie walutę, na każde żądanie, za określoną ilość złota. Nowa instytucja miała więc z jednej strony kierować się zasadami tego systemu i dbać o zapewnienie odpowiedniej proporcji między banknotami i depozytami a rezerwami tego szlachetnego kruszcu, z drugiej zaś - kierować się teorią weksli realnych, co miało chronić gospodarkę amerykańską przed zaburzeniami wynikającymi ze spekulacji na rynkach finansowych oraz na Giełdzie Papierów Wartościowych w Nowym Jorku (the New York Stock Exchange). Jednak wybuch pierwszej wojny światowej, a następnie przystąpienie do niej Stanów Zjednoczonych, sprawiły, iż polityka Rezerwy Federalnej została podporządkowana innym celom, co przejawiało się dążeniem do utrzymania $\mathrm{w}$ długim czasie stabilności (niskich) stóp procentowych. $\mathrm{Na}$ marginesie zaznaczyć trzeba, że samo utworzenie banku centralnego i scentrali-

14 Por. Z. Karpiński, Bankowość w krajach kapitalistycznych. Problemy teorii i praktyki, Państwowe Wydawnictwo Naukowe, Warszawa 1961, s. 362-365; C. Kosikowski, Publiczne prawo bankowe, Polskie Wydawnictwo Ekonomiczne, Warszawa 1999, s. 29; D. R. Kamerschen, R. B. McKenzie, C. Nardinelli, Ekonomia, Fundacja Gospodarcza NSZZ „Solidarność”, Gdańsk 1993, s. 187; P. A. Samuelson, W. D. Nordhaus, op. cit., s. 195; M. N. Rothbard, Tajniki bankowości. Podręcznik akademicki, Fijor Publishing Company, Warszawa 2007, s. 249-250; The Fed Today, Federal Reserve Bank of Dallas, tekst zaczerpnięty został z oficjalnej strony internetowej Regionalnego Banku Rezerwy Federalnej w Dallas, dostępnej pod adresem: http://www.dallasfed.org/educate/pubs/fedtoday.html, s. 1.

15 Por. J. K. Solarz, Rozwój systemów bankowych, Biblioteka Menedżera i Bankowca, „Zarządzanie i Finanse", Warszawa 1996, s. 53. 
zowanie w skarbcach dwunastu Regionalnych Banków Rezerwy Federalnej narodowych rezerw złota automatycznie przełożyło się na możliwość zwiększenia podaży pieniądza, a zarazem obniżenia rynkowych stóp procentowych, co w połączeniu $\mathrm{z}$ ujednoliceniem stopy rezerwy obowiązkowej na terenie całego kraju tworzyło nowoczesny i sprawnie działający system monetarny, a to z kolei miało pierwszorzędne znaczenie wobec spodziewanego wybuchu wojny w Europie. Dzięki tej reformie prywatne instytucje finansowe na terenie USA, a niezależnie od ich postawy także Departament Skarbu, mogły zaofiarować państwom Ententy znaczące subsydia i kredyty bez obaw wyzwolenia tendencji deflacyjnych $w$ rodzimej gospodarce, pomagając tym samym $w$ sfinansowaniu wydatków militarnych sojuszników politycznych Stanów Zjednoczonych.

Stabilność stóp procentowych, a dokładniej, niechęć do ich dużych zmian (interest - rate smoothing), była od samego początku istnienia Systemu Rezerwy Federalnej ważnym czynnikiem determinującym zachowanie banku centralnego, gdyż właśnie duże, w znacznej części sezonowe zmiany nominalnych stóp procentowych uważano za jedną z najważniejszych przyczyn wcześniejszych kryzysów finansowych, które zawsze pociągały za sobą panikę bankową. Z dzisiejszego punktu widzenia niezwykle istotny jest fakt, iż $\mathrm{w}$ dyskusjach $\mathrm{z}$ owego okresu, a co gorsza nawet podczas wielkiego kryzysu lat 1929-1933, nie rozróżniano nominalnych i realnych stóp procentowych. W okresie wojny dodatkową zachętą do utrzymywania stabilnych stóp procentowych był ustawowy, nałożony na podstawie trzeciej ustawy o pożyczce na rzecz wolności (the Third Liberty Loan Act) z 1918 r., obowiązek stabilizowania długoterminowych stóp procentowych obligacji rządowych. Innymi słowy oznaczało to, iż jakiekolwiek działania Rezerwy Federalnej nakierowane na podniesienie stóp procentowych powyżej pewnego poziomu stałyby w sprzeczności nie tylko z działaniami Departamentu Skarbu, ale i z decyzjami Kongresu ${ }^{16}$.

Intencją twórców ustawy o Rezerwie Federalnej było wreszcie zapewnienie większej stabilności narodowemu systemowi bankowemu poprzez ustanowienie pożyczkodawcy ostatniej instancji dla jego uczestników, zwłaszcza dla dużych instytucji finansowych zagrożonych chwilową niewypłacalnością. Dwanaście banków Rezerwy Federalnej rozmieszczonych na terytorium całego kraju miało równoważyć fluktuacje w popycie i podaży kredytu przez udzielanie pożyczek dyskontowych w nowej walucie federalnej dla banków komercyjnych oraz innych podmiotów finansowych pod zastaw posiadanych przez nie papierów wartościowych, w tym obligacji i bonów emitowanych przez Departament Skarbu, rządy poszczególnych stanów, a także inne jednostki samorządu tery-

16 Por. R. Kokoszczyński, Wspótczesna polityka pieniężna w Polsce, Polskie Wydawnictwo Ekonomiczne, Warszawa 2004, s. 65-66 i zamieszczony tam przypis 11; E. S. Harris, Fed Bena Bernanke, s. 158 M. N. Rothbard, op. cit., s. 254-258; G. B. Tindall, D. E. Shi, Historia Stanów Zjednoczonych, s. 948. 
torialnego. W zamian za obietnicę uzyskania płynności członkowskie banki handlowe musiały z mocy prawa utrzymywać na nieoprocentowanym rachunku w Regionalnym Banku Rezerwy Federalnej niewielką rezerwę obowiązkową ${ }^{17}$. W ten sposób bank centralny miał stworzyć sprawny mechanizm redyskontowania weksli handlowych i papierów wartościowych, a zatem dostarczyć elastyczny pieniądz, co miało na celu uniknięcie przyszłych zaburzeń finansowych, którym zazwyczaj towarzyszyła panika bankowa ${ }^{18}$.

4. Dopowiedzieć w tym miejscu trzeba, że charakterystyczną cechą rozwoju gospodarczego Stanów Zjednoczonych od ustanowienia pierwszego banku centralnego tego państwa w $1791 \mathrm{r}$. do wybuchu drugiej wojny światowej w $1939 \mathrm{r}$. było występowanie na rynku finansowym, w związku z pojawieniem się regularnego cyklu koniunkturalnego (czyli okresowych wahań produkcji i zatrudnienia), bardzo silnych tendencji deflacyjnych, których zwieńczeniem były kryzysy finansowe oraz paniki bankowe. Towarzyszyła im nadprodukcja, poprzedzona zazwyczaj spekulacją. Kryzysy takie do wybuchu wojny secesyjnej i uchwalenia ustawy o bankach narodowych (the National Bank Act) z 3 czerwca 1864 r. pojawiały się mniej więcej co dwadzieścia lat: w latach 1819, 1837 (najdłuższy w XIX w., trwający cztery lata) i 1857. Po utworzeniu systemu bankowości narodowej (national banking system) częstotliwość kryzysów finansowych i panik bankowych zwiększyła się jednak dwukrotnie; występowały one w przybliżeniu co dziesięć lat po zakończeniu wojny domowej: w latach 1873, 1884, 1893 i $1907^{19}$.

Główną przyczyną takiego stanu rzeczy była niezdolność narodowego systemu bankowego do prowadzenia elastycznej polityki pieniężnej, wynikająca ze sztywnego powiązania wielkości emisji banknotów poszczególnych banków narodowych z wartością rynkową, nie zaś nominalną, funduszy własnych złożonych z obligacji Departamentu Skarbu. Mianowicie, skoro artykuł 21 ustawy o bankach narodowych przyznał dla banku komercyjnego działającego na podstawie licencji wydawanej przez Urząd Kontrolera Obiegu prawo emisji własnych banknotów do wysokości 90\% wartości rynkowej posiadanych papierów wartościowych rządu federalnego, które uprzednio musiały zostać zdeponowane w regionalnym oddziale Niezależnego Skarbu Państwa, oznaczało to, że wolu-

17 Por. D. C. Wheelock, Conducting Monetary Policy Without Government Debt: The Fed's Early Years, „Review of the Federal Reserve Bank of St. Louis”, Volume 83, Number 3, The Research Division of the Federal Reserve Bank of St. Louis, 2002, s. 3-4.

18 Por. J. Głuchowski, op. cit., s. 17.

19 Por. F. S. Mishkin, Ekonomika pieniądza, bankowości i rynków finansowych, s. 278; J. K. Solarz, op. cit., s. 54; M. Deane, R. Pringle, The Central Banks, Viking Penguin, New York 1994, s. 51; R. S. Grossman, US Banking History, Civil War to World War II, tekst został zaczerpnięty ze strony internetowej dostępnej pod adresem: http://eh.net/encyclopedia/article/grossman.banking.history. us.civil.war.wwii, s. 5 . 
men pieniądza bankowego w gospodarce amerykańskiej uzależniony został od cen rynkowych obligacji rządowych, a nie rzeczywistych potrzeb obrotu gospodarczego. Tak więc, jeśli cena federalnych papierów wartościowych spadała (co rzeczywiście miało miejsce), wówczas banki narodowe musiały zredukować podaż pieniądza w obiegu. Odbywało się to poprzez zahamowanie udzielania pożyczek bankowych lub, co było o wiele bardziej drakońskim środkiem, wezwania do ich natychmiastowego zwrotu. Równocześnie sztywne powiązanie między ilością pieniądza i ograniczonymi zasobami złota, srebra czy obligacji rządowych wywoływało znaczne wahania stóp procentowych, związane z sezonowym wzrostem zapotrzebowania na kredyty w rolnictwie i okresowym zwiększeniem tego zapotrzebowania w biznesie, $\mathrm{w}$ wyniku cyklu koniunkturalnego. Innymi słowy, pozbawienie banków krajowych prawa okresowej emisji banknotów (np. co pięć lat) na kwotę większą od wartości przechowywanych przez nie w skarbcu federalnym obligacji rządowych, powodowało brak elastyczności podaży pieniądza oraz nadmierne oprocentowanie kredytów inwestycyjnych oraz na cele produkcyjne, co generowało z kolei ataki paniki bankowej i recesji w systemie gospodarczym. W rezultacie system bankowości narodowej nie był w stanie zapewnić równowagi na rynku pieniężnym i międzybankowym, jak byłoby to możliwe w przypadku utworzenia banku centralnego wzorowanego na rozwiązaniach europejskich. Oprócz tego poważnym obciążeniem w prowadzeniu działalności operacyjnej banku narodowego był zakaz udzielania pożyczek bankowych zabezpieczonych hipotecznie na gospodarstwach rolnych, co jeszcze bardziej osłabiało i tak relatywnie niską zdolność kredytową farmerów. Słowem, system banków narodowych nie mógł zagwarantować odpowiedniej ilości kredytów sezonowych dla sektora rolniczego, co powodowało faktyczne wykluczenie grupy społecznej farmerów z uczestnictwa w rynku finansowym i powodowało zmniejszenie możliwości nabywczych społeczeństwa. Z drugiej strony największe banki narodowe, tzw. Centralne Miejskie Banki Rezerwy w Nowym Jorku dysponujące rezerwami bankowymi wielu tysięcy pozostałych banków należących do systemu, przeznaczały je nie na podtrzymywanie płynności finansowej jego uczestników, lecz na udzielanie kredytów umożliwiających spekulacyjny obrót papierami wartościowymi na rynku kapitałowym.

Niezdolność Systemu Banków Narodowych do stworzenia skutecznego mechanizmu alokacji posiadanego kapitału nadwyżkowego do banków handlowych zagrożonych niewypłacalnością w okresie kryzysu finansowego, recesji bądź charakteryzujących się okresowym niedopasowaniem zapadalności aktywów z wymagalnością pasywów, wynikała - obok nieelastycznej podaży pieniądza - przede wszystkim z jego nadmiernie zdecentralizowanej i rozbudowanej struktury. W założeniu ustawodawcy stworzenie trójstopniowej struktury systemu bankowości narodowej miało na celu zmniejszenie ryzyka niewypłacalności i upadłości należącego doń przedsiębiorstwa bankowego oraz wyeliminowanie zjawiska paniki bankowej. $\mathrm{Z}$ tego względu na mniejsze banki 
należące do systemu nałożono prawny obowiązek utrzymywania depozytów (część funduszy własnych) w większych bankach narodowych. I tak najmniejsze Banki Krajowe (Country Banks) trzymały część swoich rezerw obowiązkowych w Miejskich Bankach Rezerwy (Reserve City Banks) lub Centralnych Miejskich Bankach Rezerwy (Central Reserve City Banks). Natomiast Miejskie Banki Rezerwy, którymi były wszystkie banki narodowe zlokalizowane w 47 wybranych miastach powyżej 500 tysięcy mieszkańców, musiały utrzymywać połowę swoich rezerw obowiązkowych w Centralnych Miejskich Bankach Rezerwy. Status Centralnych Miejskich Banków Rezerwy początkowo posiadały jedynie wszystkie banki narodowe z siedzibą w Nowym Jorku, ale dość szybko okazało się, że same nie są w stanie zapewnić stabilności dla całego systemu. $\mathrm{Z}$ tego powodu status taki przyznano po 1887 r. także bankom narodowym z Chicago i St. Louis. Nie zapobiegło to jednak „spiętrzaniu rezerw” w największych bankach Nowego Jorku, które wykorzystywały te środki finansowe do gwarantowania emisji papierów wartościowych przedsiębiorstw przemysłowych. Stymulowało to jedynie narastanie boomu spekulacyjnego na nowojorskiej Giełdzie Papierów Wartościowych, podczas gdy w tym samym czasie banki krajowe dysponowały zbyt małymi rezerwami obligacji Skarbu Państwa, by zaspokoić uzasadnione potrzeby kredytowe lokalnej społeczności, zwłaszcza drobnych kupców, rzemieślników i farmerów ${ }^{20}$.

Wreszcie, brak zasadniczych reform ustroju pieniężnego państwa w okresie od 1870 do 1913 r. wynikał także z przeświadczenia ówczesnych władz monetarnych utożsamiających stabilność cenową w skali makro ze stabilnością finansową. Niestety, o ile poziom inflacji był stale bliski ideału (w szczytowym momencie obowiązywania w Stanach Zjednoczonych systemu waluty złotej, między rokiem 1870 a 1913 koszty życia rosły średnio o zaledwie 0,2 procenta rocznie), wyniki gospodarcze prezentowały się wręcz fatalnie. W omawianym okresie gospodarka Stanów Zjednoczonych przez $48 \%$ czasu była pogrążona $\mathrm{w}$ recesji. Średnie trwanie prosperity wynosiło 24 miesiące, kryzysy zaś trwały średnio po 23 miesiące. Na przestrzeni lat okazywało się zatem, że sztywne reguły systemu waluty złotej oraz plafonu emisji banknotów uniemożliwiały największym instytucjonalnym uczestnikom rynków finansowych nie tylko walkę

20 Por. M. N. Rothbard, op. cit., s. 237-252; S. Solomon: Gra o zaufanie. Jak, nie pochodzacy z wyboru szefowie banków centralnych, rządza przekształcona gospodarką globalna, Philip Wilson, Warszawa 2000, s. 203; M. A. Jones, Historia USA, s. 440; P. Trescott, op. cit., s. 744; R. T. Johnson, Historical Beginnings... The Federal Reserve, Public and Community Affairs Department, Federal Reserve Bank of Boston 1999, tekst został zaczerpnięty z oficjalnej strony internetowej Regionalnego Banku Rezerwy Federalnej w Bostonie, dostępnej pod adresem: www.bos.frb.org/about/pubs/begin.pdf, s. 11-15; E. Flaherty, A Brief History of Central Banking in the United States, s. 11-14; tekst ustawy o bankach narodowych z 3 czerwca 1864 r. (National Currency Act) zaczerpnięty został ze strony internetowej dostępnej pod adresem: http://landru.i-link-2.net/monques/currencyact.html\#NATIONAL. 
z recesją, lecz to właśnie je można było uznać za czynniki kryzysogenne. $Z$ drugiej jednak strony, parytet złota i ustalony administracyjnie pułap emisyjny był dobrą metodą narzucania pewnej dyscypliny na działalność operacyjną banków prywatnych (narodowych i stanowych), ponieważ instytucje te tworzyły pieniądze poprzez rozszerzanie pożyczek $\mathrm{w}$ postaci wydawanych banknotów, w związku z czym zawsze istniało ryzyko wyprodukowania zbyt dużej ilości weksli. I chociaż bankierzy - wystawcy banknotów - zauważyli, iż nie ma potrzeby utrzymywania w skarbcu pełnego pokrycia w kruszcu lub państwowych papierach wartościowych dla emitowanych banknotów, gdyż z reguły tylko niektórzy deponenci w danym czasie zgłaszają się, aby dokonać wymiany biletów bankowych na zdeponowany kruszec złota lub weksle skarbowe, to jednak od czasu do czasu zdarzało się, że bank mógł znaleźć się w sytuacji uniemożliwiającej sprostanie życzeniom klientów i ogłosić bankructwo. Tym bardziej, że działalność polegająca na emisji banknotów stała się niezwykle lukratywna. Nic więc dziwnego, że w sytuacji braku kredytodawcy ostatniej instancji mnożyły się przypadki niewypłacalności i bankructwa banków, następowały zakłócenia wymiany handlowej i całej gospodarki. Oczywiście bankructwo mogło być rezultatem złego zarządzania lub trudności obiektywnych, jak klęska żywiołowa uniemożliwiająca kredytobiorcom spłatę pożyczek czy też kłopoty z transportem. Mimo to coraz częściej przyczyną upadłości było zjawisko fałszowania pieniędzy. Ponadto sfałszowane banknoty podnosiły koszt informacji koniecznych przy stosowaniu banknotów i ograniczały ich ogólną akceptowalność. Co gorsza, ponieważ banki trzymały swe depozyty $w$ innych bankach, finansowe kłopoty jednego $\mathrm{z}$ nich rozszerzały się na cały system bankowy. Działo się tak dlatego, ponieważ banki działające w oparciu o system rezerw ułamkowych nie miały (i w dalszym ciągu nie mają) wystarczających rezerw do spełnienia żądań swych klientów w okresie rozszerzającej się paniki. Tak więc bank pod naciskiem swoich klientów mógł wycofać swe depozyty $\mathrm{z}$ innego banku. Zauważywszy to posunięcie, klienci tego banku mogli stracić poczucie bezpieczeństwa swoich depozytów i również dokonać próby ich wycofania. W rezultacie, wszystkie banki w mieście, a w szczególnej sytuacji niewykluczone że i w całym kraju, mogły zbankrutować w prawie tym samym czasie, powodując dramatyczne zmniejszenie się zasobów pieniężnych oraz cen dóbr i usług.

W okresie rozszerzającego się procesu upadłości banków przedsiębiorstwa odkrywały, iż realna wartość ich zobowiązań finansowych wzrastała. Ceny ich aktywów i dochodów obniżały się, podczas gdy wartość ich długów liczona $\mathrm{w}$ dolarach pozostawała bez zmian. Wiele przedsiębiorstw, niezdolnych do wytrzymania takiego nacisku finansowego, również bankrutowało, rozrywając w ten sposób normalny rytm działalności gospodarczej. W tym samym czasie dramatyczne obniżenie się cen podnosiło wartość realnej stawki płac. Konsekwencją był spadek popytu na pracę i wzrost bezrobocia. W takiej sytuacji, chociaż na wolnym rynku pracy nominalne i realne stawki płacy ostatecznie 
mogą przesunąć się w kierunku równowagi, w okresie załamania się banków i kurczenia się zasobów pieniądza bezrobocie na wysokim poziomie będzie się utrzymywać. Toteż w praktyce chodziło o to, aby wzrostowi produkcji i wymiany handlowej towarzyszyło zwiększenie emisji banknotów, a spadkowi aktywności gospodarczej - wycofanie ich części z obiegu. Tymczasem okresowo dawał się odczuć to brak, to nadmiar pieniądza. I rzeczywiście: na przestrzeni lat dokonywano szeregu prób w celu skorygowania powyższej niestabilności wczesnego systemu bankowego. Jednak przyjęcie systemu waluty złotej, w ramach którego wzrost podaży pieniądza był ściśle uzależniony od ilości złota w sztabach oraz ustalony pułap emisji pieniądza wydatnie uniemożliwiały nie tylko uchronienie społeczeństwa przed załamaniem się systemu bankowego, ale tym bardziej nie mogły zabezpieczać przed wystąpieniem znacznej deflacji i towarzyszącym jej problemom recesji gospodarczej i bezrobocia ${ }^{21}$.

W konkluzji należy stwierdzić, że nieelastyczny pieniądz (inelastic currency) oraz niewykształcenie się mechanizmu rozliczeń międzybankowych (immobile reserves) zadecydowały o tym, że narodowy system bankowy nie mógł skutecznie przeciwdziałać poważnym zaburzeniom na rynkach finansowych, mimo że $\mathrm{w}$ utrzymaniu ich stabilności wspomagany był przez inne elementy bankowości centralnej, w szczególności przez Departament Skarbu, Niezależny Skarb Państwa oraz prywatne Izby Rozrachunkowe. Pojawiające się w przybliżeniu co dziesięć lat poważne zaburzenia na rynkach finansowych, charakteryzujące się gwałtownym spadkiem cen aktywów oraz upadłością wielu przedsiębiorstw i instytucji finansowych, które za każdym razem przeobrażały się w ogólnokrajową panikę bankową, ostatecznie przekonały amerykańskie społeczeństwo, bankierów i elity polityczne do idei utworzenia banku centralnego ${ }^{22}$.

5. Detonatorem zmian w organizacji krajowego systemu bankowego była wielka panika bankowa, jaka ogarnęła Stany Zjednoczone w 1907 r. ${ }^{23}$ Była ona skutkiem zakończenia wojny rosyjsko-japońskiej, trzęsienia ziemi w San Francisco oraz pokłosiem walki konkurencyjnej Johna D. Rockefellera z koncernem United Copper ${ }^{24}$. Okazała się ona szczególnie dotkliwa dla amerykańskiego społeczeństwa, które poniosło ogromne straty związane z niewypłacalnością wielu

21 Por. E. S. Harris, op. cit., s. 136-137; W. Baka, op. cit., s. 326; D. R. Kamerschen, R. B. McKenzie, C. Nardinelli, op. cit., s. 252 i 254; A. Kaźmierczak: Polityka pieniężna w gospodarce otwartej, Wydawnictwo Naukowe PWN, Warszawa 2008, s. 21-23; idem, Kreacja pieniadza w systemie bankowym, [w:] Bankowość. Podręcznik akademicki, red. W. L. Jaworski, Z. Zawadzka, Poltext, Warszawa 2007, s. 98-99.

22 Por. F. S. Mishkin, op. cit., s. 492-493.

23 Por. W. Baka, Bankowość centralna. Funkcje, metody, organizacja, Biblioteka Menedżera i Bankowca, „Zarządzanie i Finanse”, Warszawa 2001, s. 262.

24 Por. W. Morawski, Historia finansów współczesnego świata od 1900 roku, Centrum Doradztwa i Informacji Difin, Warszawa 2009, s. 14. 
tysięcy instytucji pośrednictwa finansowego i błyskawicznym wzrostem stopy bezrobocia, które na jesieni tego roku wynosiło $20 \%$ osób aktywnych zawodowo $^{25}$. Zaznaczyć przy tym trzeba, że podczas paniki bankowej 1907 r., odwrotnie niż podczas kryzysów XIX-wiecznych, spadły nie tyle ceny, co produkcja. Był to skutek zmonopolizowania znacznej części gospodarki amerykańskiej. Dzięki temu przedsiębiorstwa przemysłowe i instytucje finansowe mogły zarazem skutecznie przerzucić koszty „ściśnienia” aktywności gospodarczej na najszersze warstwy społeczne, zwłaszcza drobnych ciułaczy, konsumentów i robotników ${ }^{26}$. Panika ta zapoczątkowana została przez ostre spadki cen akcji spółek notowanych na Giełdzie Papierów Wartościowych w Nowym Jorku, które zajmowały się eksportem do państw europejskich miedzi, rudy żelaza i węgla. Mimo to przez wiele kolejnych miesięcy wydawało się, że bessa na Wall Street nie przełoży się na stan gospodarki realnej. Oświadczenie Narodowego Banku Handlowego (the National Bank of Commerce) z 21 października 1907 r. o zaprzestaniu udzielania bankowych certyfikatów pożyczkowych (clearinghouse loan certificates) dla trzeciego co do wielkości w Nowym Jorku towarzystwa powierniczego the Knickerbocker Trust Company, zajmującego się sprzedażą w ofercie publicznej papierów wartościowych innych spółek oraz ich ubezpieczeniem przed ryzykiem spadku ceny tych walorów, a jednocześnie posiadającego depozyty bankowe o łącznej wartości 62 milionów dolarów, zadecydowało jednak o tym, że trwający od 13 marca 1907 r. spadek wartości indeksów giełdowych był jedynie zwiastunem nadchodzącego kryzysu finansowego ${ }^{27}$. Teoretycznie, w takiej sytuacji Departament Skarbu, aby podtrzymać zaufanie do systemu bankowego oraz $\mathrm{w}$ celu zahamowania drastycznego spadku podaży pieniądza, powinien był niezwłocznie przenieść fundusze rządowe do zagrożonego niewypłacalnością trustu, ale sekretarz skarbu George B. Cortelyou (1907-1909) obawiał się, że może to spowodować zbyt duże zmniejszenie federalnych rezerw złota, które od 1873 r. faktycznie, a od 1900 formalnie stanowiły podstawę amerykańskiego systemu płatniczego. Zresztą drenaż tego szlachetnego kruszcu, przechowywanego w kilkudziesięciu podziemiach Niezależnego Skarbu Państwa, od początku 1907 r. przybrał potężne rozmiary, ponieważ banki centralne Wielkiej Brytanii i Niemiec, zaniepokojone znaczącym odpływem złota do USA w latach 1903-1906 na skutek dużego importu minerałów z tego kraju, we wrześniu i październiku $1906 \mathrm{r}$. podniosły stopę procentową ${ }^{28}$. Z tej przyczyny sekretarz

25 Por. E. Flaherty, op. cit., s. 13.

26 Por. W. Morawski, op. cit., s. 14.

27 Por. M. Friedman, A. J. Schwartz, A Monetary History of the United States 1867-1960, Princeton University Press, Princeton - New York 1963, s. 156-159; M. i R. Friedman, Wolny wybór, Wydawnictwo Aspekt, Sosnowiec 2006, s. 67; J. Moen, The Panic of 1907, tekst został zaczerpnięty ze strony internetowej pod adresem: http://eh.net/encyclopedia/article/moen.panic.1907, s. 1-3. 
skarbu w pierwszej kolejności starał się nie dopuścić do powtórzenia się sytuacji, jaka miała miejsce po ustąpieniu paniki bankowej z 1893 r., kiedy rezerwy złota w gestii Skarbu Państwa spadły do alarmująco niskiego poziomu $45 \mathrm{mi}$ lionów dolarów w lutym 1895 r. i dlatego nie zgodził się na udzielenie pomocy finansowej dla tego przedsiębiorstwa reasekuracyjnego ${ }^{29}$. Niezależnie wszak od decyzji Skarbu Państwa, kredyt na przywrócenie płynności finansowej powinien był zostać przyznany przez banki narodowe z siedzibą w stanie Nowy Jork, które z mocy prawa zobowiązane były do podtrzymywania stabilności całego systemu bankowego. Mimo to na specjalnym posiedzeniu wieczorem 21 października odmówiły one udzielenia kredytu dla the Knickerbocker Trust Company, wskazując, że bank ten jest licencjonowany na podstawie prawa stanowego i nie jest członkiem systemu bankowości narodowej. Podobnie postąpiła nowojorska Izba Rozrachunkowa, uzasadniając swoje stanowisko tym, że instytucja ta nie została przyjęta w poczet tej prywatnej korporacji.

Niemożność uzyskania źródeł refinansowania działalności operacyjnej i pojawienie się masowych żądań klientów dążących do wycofania swoich wkładów zmusiły zarząd the Knickerbocker Trust Company do zamknięcia tej instytucji 22 października. Wydarzenie to spowodowało załamanie nowojorskiego sektora towarzystw powierniczych w dniu następnym i wywołało panikę bankową, która w ciągu zaledwie jednego tygodnia doprowadziła do całkowitego zaprzestania lub ograniczenia działalności depozytowo-kredytowej i na rynkach papierów wartościowych przez instytucje pośrednictwa finansowego na terytorium całego kraju. Aby odbudować zaufanie społeczne do systemu bankowego i zatrzymać błyskawiczne rozprzestrzenianie się paniki bankowej (contagion effect) sekretarz skarbu za zgodą Prezydenta Stanów Zjednoczonych, Theodore’a Roosevelta, zaproponował wieczorem 23 października Johnowi Pierpontowi Morganowi zawarcie porozumienia, na mocy którego Skarb Państwa przekazywał do jego dyspozycji środki budżetowe, które miały być przeznaczone do zapobieżenia niewypłacalności oraz upadłości banków w tym stanie. Następnego ranka, wykonując postanowienia tej umowy, Cortelyou przeniósł rządowe fundusze w wysokości 25 milionów dolarów do skarbców banków narodowych w Nowym Jorku. Równocześnie J. P. Morgan zorganizował fundusz gwarancyjny dysponujący analogicznym kapitałem, który miał spełniać funkcje „pożyczkodawcy ostatniej instancji" wobec wszystkich nowojorskich instytucji finansowych, $\mathrm{w}$ tym towarzystw powierniczych, co miało przywrócić normalne funkcjonowanie rynkowi finansowemu. Działania te zderzyły się jednak z załamaniem cen papierów wartościowych na giełdzie Wall Street. W celu ustabilizowania sytu-

29 Por. J. Moen, E. Tallman, New York and the Politics of Central Banks, 1781 to the Federal Reserve Act, Federal Reserve Bank of Atlanta 2003, tekst zaczerpnięty został z oficjalnej strony Banku Rezerwy Federalnej w Atlancie pod adresem: http://www.frbatlanta.org. Click on the „Publications” link and then „Working Papers”, s. 18. 
acji na rynku kapitałowym 25 października Morgan, przy finansowym wsparciu m.in. J. D. Rockefellera, utworzył nowy pul (pool) o wartości 12,5 miliona dolarów. Mimo to silna tendencja spadkowa na rynku kapitałowym trwała nadal i utrzymała się aż do 15 listopada 1907 r., kiedy to osiągnęła swój najniższy punkt; średnia cena papierów wartościowych spółek giełdowych obniżyła się o 39\% w porównaniu z przeciętną ceną walorów giełdowych z 13 marca $1907 \mathrm{r}$. (dzień ten zapoczątkował bessę na nowojorskiej GPW). Tym niemniej, w dłuższej perspektywie przejęcie odpowiedzialności za walkę z paniką bankową przez największe prywatne instytucje finansowe znajdujące się pod kontrolą „króla bankierów" J. P. Morgana oraz przystosowanie ich do udzielania pożyczek zagrożonym upadłością pośrednikom finansowym, relatywnie szybko, bo już w lutym 1908 r., doprowadziło do definitywnego zakończenia paniki bankowej $\mathrm{w}$ tym stanie. To zaś niemal automatycznie przełożyło się na uzdrowienie sytuacji na rynkach finansowych w całym kraju. Ostatecznie, na wiosnę system bankowy wznowił normalną działalność. Nie bez znaczenia było także rozpoczęcie przez Dom Rozrachunkowy w Nowym Jorku emisji bankowych certyfikatów pożyczkowych, co umożliwiło dla Miejskich Banków Rezerwy zarówno zwrócenie mniejszym uczestnikom systemu ich funduszy własnych, jak również poluzowanie warunków udzielania kredytu. Przełamaniu tendencji deflacyjnych służyła też pożyczka Banku Anglii. Niemniej jednak, aż do wybuchu pierwszej wojny światowej wzrost gospodarczy był niewielki, a społeczeństwo amerykańskie utraciło zaufanie do systemu bankowego ${ }^{30}$.

6. Reasumując, panika bankowa 1907 r. ujawniła wszelkie słabości systemu bankowego Stanów Zjednoczonych wynikające z braku pożyczkodawcy ostatniej instancji, który mógłby stanowić dyskrecjonalne źródło rezerw dla pojedynczego banku lub systemu bankowego w reakcji na niekorzystny szok, powodujący wzrost zapotrzebowania na pieniądz rezerwowy, które nie może zostać zaspokojone z alternatywnych źródeł. Zaznaczyć przy tym trzeba, że rolę pożyczkodawcy ostatniej instancji (lender of last resort) dla banków i innych uczestników systemu bankowego może pełnić nie tylko bank centralny, ale jedynie bank centralny jest w stanie zapewnić tego rodzaju pomoc dla całego systemu bankowego. Pokazała to z całą mocą panika bankowa 1907 r., podczas której pełniący funkcje

30 Por. M. Friedman, A. J. Schwartz, op. cit., s. 159-168 i 173-174; J. Moen, op. cit., s. 2-5; R. LeRoy Miller, D. D. van Hoose, op. cit., s. 304-305; W. Morawski, Zarys powszechnej historii pieniadza i bankowości, TRIO, Warszawa 2002, s. 254; idem, Historia bankowości centralnej - System Rezerwy Federalnej, „Bank i Kredyt”, październik 2001, s. 7; H. Brogan, Historia Stanów Zjednoczonych Ameryki, Zakład Narodowy im. Ossolinnskich, Wrocław 2004, s. 508-509; History of the Treasury. Chronology of Events, tekst zaczerpnięty został z oficjalnej strony Departamentu Skarbu Stanów Zjednoczonych pod adresem: http://www.ustreas.gov/education/history/events/1900-presents. shtml, s. 2. 
banku centralnego Departament Skarbu okazał się zupełnie niezdolny nie tylko do dostarczenia rezerw do systemu bankowego, ale nie był w stanie uzupełnić płynności zaledwie jednej instytucji finansowej. Podobnie pul zorganizowany z inicjatywy J. P. Morgana, który uratował system bankowy Nowego Jorku przed zupełną upadłością, posiadał zbyt małe środki, aby funkcję pożyczkodawcy ostatniej instancji rozszerzyć na wszystkie podmioty bankowe w Stanach Zjednoczonych. Warto przy tym skonstatować, że funkcję pożyczkodawcy ostatniej instancji bank centralny wykorzystywałby do tego, aby kryzys płynności w bankach nie przekształcił się w kryzys wypłacalności m.in. po to, żeby ograniczyć nagłą i masową wyprzedaż aktywów przez banki dążące do zwiększenia stanu środków na swoich rachunkach. Miałoby to na celu zapobieżenie drastycznym spadkom cen aktywów, które finalnie mogłyby prowadzić do strat w innych instytucjach finansowych, a nawet utraty przez nie wypłacalności. Ostatecznym celem działania banku centralnego jest bowiem niedopuszczenie do kryzysu finansowego lub paniki bankowej i zahamowanie reakcji łańcuchowej na wczesnym etapie, zanim zdoła się ona rozprzestrzenić na cały system finansowy lub dużą jego część. Tego zaś nie można powiedzieć o instytucjach finansowych należących lub kontrolowanych przez J. P. Morgana, który na początku dążył do wyeliminowania konkurencyjnego towarzystwa powierniczego z rynku i przez to prawdopodobnie zaprzepaścił szansę niedopuszczenia do paniki bankowej.

Bank centralny miałby więc przejąć od Departamentu Skarbu oraz prywatnych instytucji finansowych pełną odpowiedzialność za ochronę gospodarki narodowej przed skutkami kryzysów finansowych i wspieranie bezpieczeństwa systemu bankowego. Ponieważ jednak między poszczególnymi regionami Stanów Zjednoczonych występowały poważne różnice $\mathrm{w}$ stopniu rozwoju społeczno-gospodarczego oraz ze względu na to, że amerykański system bankowy składał się ówcześnie z około trzydziestu tysięcy samodzielnych banków, uznano, że nowy federalny bank centralny nie powinien być bytem jednorodnym, wzorowanym na europejskim modelu bankowości centralnej, ale korporacją publiczno-prywatną, zrzeszającą z mocy prawa - obok, oczywiście, banku centralnego - przynajmniej banki licencjonowane przez Urząd Administratora Waluty, które miały obowiązek przestrzegania dodatkowych, wynikających z przynależności do tego systemu, a w przyszłości także wydanych przez nadzór ostrożnościowy banku centralnego, regulacji. Jak widać, w pierwszym rzędzie na ustanowieniu federalnego banku centralnego miały skorzystać głównie duże i silne banki, których właściciele - w przeważającej części elita finansowa kraju z Wall Street - mogła dzięki temu skoncentrować się na przeprowadzaniu operacji giełdowych, licząc na to, że w przypadku chwilowej niewypłacalności ich instytucje finansowe będą mogły zawsze otrzymać kredyt na warunkach korzystniejszych od rynkowych. Idea utworzenia banku centralnego stała się także korzystna dla pozostałych warstw społeczeństwa. Panika bankowa 1907 r. ujaw- 
niła bowiem bardzo wyraźnie, że uruchomienie kredytów dla amerykańskich przedsiębiorstw i konsumentów w trakcie gwałtownego „kurczenia się” gospodarki stanowi główny czynnik przeciwdziałania dla postępującej recesji oraz zahamowania negatywnych zjawisk gospodarczych, które najbardziej odbijają się na i tak najuboższych grupach społecznych. Jednocześnie zaczęto dostrzegać, że w okresie gwałtownych spadków na rynku kapitałowym i wynikającej z tego dużej niepewności na rynkach finansowych tysiące niewielkich banków prywatnych nie mogły samoczynnie przywrócić zaufania społeczeństwa do systemu bankowego, giełdy oraz mechanizmów gospodarczych. Skutkiem tego depozytariusze woleli zlikwidować rachunki bankowe i trzymać pieniądze „pod materacem”. Powodowało to z kolei, że zarówno wielkie korporacje, jak również niewielkie spółki rodzinne jeszcze bardziej zaczynały odczuwać brak tanich źródeł kapitału, bez których nie mogły się rozwijać. W rezultacie były one zmuszone do ograniczenia produkcji, zmniejszenia zatrudnienia oraz zaprzestania inwestycji, po to, aby nie dopuścić do swego bankructwa. Krótko mówiąc, utworzenie „pożyczkodawcy ostatniej instancji” miało zapewnić wzrost podaży pieniądza i rozwinięcie akcji kredytowej w dobie kryzysu finansowego, i w ten sposób przyspieszyć ożywienie gospodarcze.

7. Po to, żeby uniknąć sytuacji, w której upadłość jednego banku może wywołać tzw. run (masowe zgłaszanie się klientów z zamiarem wycofania swoich wkładów) zarówno na bankrutujące, jak i stabilne banki, wskutek czego jeden upadający bank może spowodować upadek innych (sytuację tę nazywamy „efektem rozprzestrzeniania się", ang. contagion effect), co w krótkim czasie może doprowadzić do załamania całego systemu bankowego, a w konsekwencji systemu gospodarczego państwa, konieczne stało się wyposażenie banku centralnego w wyłączne prawo emisji pieniądza i odebranie tego uprawnienia pozostałym instytucjom pośrednictwa finansowego. Twórcy ustawy o Rezerwie Federalnej słusznie bowiem przewidywali, że automatycznie przełożyłoby się to również na zmniejszenie kosztów transakcyjnych funkcjonowania systemu płatniczego (systemu rozliczeń pieniężnych) oraz przyśpieszyłoby przelew środków płynnych do banków, które ich najpilniej potrzebują. W dodatku, do podstawowych zadań nowego federalnego podmiotu emisyjnego miałoby należeć zorganizowanie jednolitego krajowego systemu płatniczego w gospodarce oraz sprawowanie nad nim nadzoru. Ratio legis takiego rozwiązania leżało w spostrzeżeniu, że kryzys finansowy 1907 r. tak dotkliwie dotknął amerykańskie społeczeństwo m.in. dlatego, że ważność certyfikatów istniejących wówczas ponad 150 izb rozrachunkowych, które umożliwiały zwiększenie ilości środków płatniczych w obiegu bez konieczności emisji dodatkowej gotówki, ograniczona była do poszczególnych regionów. Innymi słowy, przyznanie dla banku centralnego monopolu na tworzenie i emisję pieniądza znajdującego się w obiegu powszechnym warunkowa- 
łoby skuteczność wywiązywania się z funkcji pożyczkodawcy ostatniej instancji. W zamian za to nowy federalny bank emisyjny, w przeciwieństwie np. do Banku Anglii, miał obsługiwać głównie państwo oraz członkowskie banki handlowe i w ogóle nie mieć do czynienia $\mathrm{z}$ indywidualnymi klientami.

Beneficjentem utworzenia banku centralnego zostałby także rząd federalny. Oprócz tego, że dotychczas nadmiernie rozproszone depozyty rządowe oraz rezerwy bankowe mogły być teraz szybko łączone we wspólnym funduszu (centralizacja dysponowania złotem), co znacznie zwiększyłoby krajową bazę ekspansji kredytowej, to do zadań banku centralnego należałoby prowadzenie rachunków bankowych rządu i innych instytucji publicznych, realizowanie ich zleceń płatniczych oraz zarządzanie rezerwami walutowymi państwa, co siłą rzeczy zapewniłoby większe bezpieczeństwo systemu bankowego, a jednocześnie umocniłoby wiarygodność finansową kraju. Z punktu widzenia Kongresu i Białego Domu nie mniej istotne było także powołanie instytucji będącej potencjalnie „kredytodawcą pierwszej instancji” dla organów władzy federalnej. Okoliczność ta miała szczególne znaczenie w sytuacji narastającego napięcia politycznego w Europie, poprzedzającego wybuch ogólnoświatowej wojny. Tak więc przyznanie bankowi centralnemu przywileju emisyjnego oznaczało umocnienie ekonomicznej i politycznej funkcji państwa („kredyt otwarty” w instytucji emisyjnej). Dzięki temu polityka finansowa banku centralnego służyłaby podtrzymaniu wzrostu gospodarczego $\mathrm{w}$ przypadku zaprzestania zewnętrznego finansowania $\mathrm{w}$ „ulepszenia wewnętrzne" na skutek wycofania zagranicznego kapitału ze Stanów Zjednoczonych przez Zjednoczone Królestwo i Francję.

Zalety ustanowienia banku centralnego wynikają również stąd, że dysponując monopolem na tworzenie pieniądza posiada on jednocześnie prerogatywę ustalania wysokości stopy dyskontowej, po której może udzielić pożyczek dla banków handlowych i w ten sposób uczynić system bankowy bezpieczniejszym i stabilniejszym. Za pośrednictwem tych instrumentów bank centralny może również regulować wielkość kreacji pieniądza bankowego, a zatem w bardziej efektywny sposób wpływać na ilość pieniądza znajdującego się w obiegu. Instrumenty polityki dyskontowej umożliwiłyby również bankowi centralnemu podjęcie w każdej chwili akcji zapobiegającej destabilizacji gospodarczej. Przyznanie mu zaś kontroli nad wzrostem masy pieniądza umożliwiłoby z kolei przejściowe jego wzrosty w sytuacjach paniki, ponieważ bank centralny - w przeciwieństwie do systemu bankowości narodowej - byłby przygotowany do tego, aby neutralizować spadek mnożnika pieniądza, wywołanego wzrostem popytu na gotówkę, poprzez zwiększenie bazy monetarnej. W efekcie podaż pieniądza utrzymywana byłaby na odpowiednim poziomie, a to amortyzowałoby spadek aktywności gospodarczej. Oprócz tego ustanowienie centralnej instytucji emisyjnej, która mogłaby rozmiary emisji dostosowywać do zmieniającej się koniunktury gospodarczej, spowodowałoby z jednej strony zmniejszenie stopy rezerwy obowiązkowej, a z drugiej, przebudowę mechanizmu gromadzenia rezerw obowiązkowych 
systemu bankowości narodowej, co samoistnie rozszerzyłoby możliwości akcji kredytowej banków handlowych. Na koniec zauważyć też trzeba, że jednolita stopa procentowa na terenie całego kraju i szybka możliwość jej zmiany przez bank centralny, wzmocniłaby odporność amerykańskiego systemu bankowego na negatywne procesy zachodzące na międzynarodowym rynku pieniężnym. Słowem, naczelnym zadaniem nowego federalnego banku centralnego miało być prowadzenie elastycznej polityki pieniężnej w celu uniknięcia zaburzeń finansowych, powodowanych nieskoordynowaną i woluntarystyczną działalnością banków oraz kontrola i regulowanie krajowego obiegu pieniężnego i transakcji międzybankowych ${ }^{31}$.

8. Najważniejszym skutkiem prawnofinansowym paniki bankowej $1907 \mathrm{r}$. było uchwalenie w maju 1908 r. przez Kongres Stanów Zjednoczonych ustawy o pieniądzu nadzwyczajnym (the Emergency Currency Act), która od nazwiska jej głównych promotorów w Senacie i Izbie Reprezentantów nazywana jest także ustawą Aldricha - Vreelanda (the Aldrich - Vreeland Act). Doraźnym celem tej ustawy było zwiększenie podaży pieniądza i w ten sposób stymulowanie obrotu prawnego, co miało z jednej strony przeciwdziałać deflacji, a z drugiej stworzyć korzystne warunki nadejścia ożywienia gospodarczego. Zaznaczyć w tym miejscu jednak trzeba, że rozszerzenie możliwości kredytowych banków narodowych nie oznaczało uchylenia artykułu 21 ustawy o bankowości narodowej, która ograniczała rozmiar emisji biletów bankowych do wartości rynkowej 90\% (później 100\%) obligacji rządu federalnego, zdeponowanych w podziemiach Niezależnego Skarbu Państwa. Prawodawca utrzymał moc obowiązującą tego przepisu, ale rozszerzył jego zakres stosowania również do papierów wartościowych rządu stanowego i innych jednostek samorządu terytorialnego. Jednocześnie banki narodowe dysponujące odpowiednimi nadwyżkami otrzymały prawo podmiotowe do emisji własnych banknotów o wartości rynkowej nieprzekraczającej 75\% akcji, które uprzednio musiały zostać zdeponowane $\mathrm{w}$ innych instytucjach należących do tego systemu. Umożliwiło to utworzenie rynku międzybankowego, na którym te instytucje finansowe udzielały sobie nawzajem pożyczek. Z kolei, aby nie dopuścić do gwałtownego wzrostu rynkowych stóp procentowych, a co za tym idzie, spadku podaży pieniądza, zahamowania inwestycji oraz osłabienia ogólnej aktywności gospodarczej w wyniku np. upadku liczącej się insty-

31 Por. F. S. Mishkin, op. cit., s. 337, 376, 492, 576 i 578; O. Szczepańska, Stabilność finansowa jako cel banku centralnego, Wydawnictwo Naukowe Scholar, Warszawa 2008, s. 94-101; S. Heffernan, Nowoczesna bankowość, Wydawnictwo Naukowe PWN, Warszawa 2007, s. 41 i 435; Ch. P. Kindleberger, Szaleństwo, panika, krach. Historia kryzysów finansowych, WIG - Press, Warszawa 1999, s. 257-259; M. N. Rothbard, Wielki Kryzys w Ameryce, Instytut Ludwiga von Misesa, Warszawa 2009, s. 19-21; W. Baka, Pieniądz, bank centralny..., s. 327; P. A. Samuelson, W. D. Nordhaus, op. cit., s. 170-171; J. Głuchowski, op. cit., s. 17-18; Z. Karpiński, op. cit., s. 384-385. 
tucji finansowej lub niefinansowej, sekretarz skarbu mógł wydawać zezwolenie dla poszczególnych banków narodowych uprawniające do dodatkowej emisji weksli bankowych, przy czym wprowadzanie do obiegu tymczasowej waluty miało być opodatkowane. Podatek miał gwarantować wycofanie tego pieniądza $\mathrm{z}$ chwilą, gdy minie krytyczna sytuacja. Warto dodać, że klauzula ta, dopuszczająca nadzwyczajną emisję pieniądza bankowego za uprzednią zgodą ministra finansów, została wykorzystana tylko raz, aby zniwelować niezwłoczne wycofanie depozytów bankowych i anulowanie sfinansowania projektów inwestycyjnych przez mocarstwa europejskie, które z chwilą wybuchu pierwszej wojny światowej musiały przeznaczyć te środki na cele wojenne. Wpompowanie do systemu bankowego i gospodarki narodowej od sierpnia do listopada 1914 r. prawie 400 milionów dolarów prawdopodobnie zapobiegło ponownemu pojawieniu się ogólnokrajowego kryzysu finansowego i umożliwiło otworzenie nowojorskiej Giełdy Papierów Wartościowych (po pięciu miesiącach przymusowego zawieszenia jej działalności) 12 grudnia 1914 r. Ostatecznie ustawa niniejsza utraciła moc obowiązującą już po rozpoczęciu działalności przez System Rezerwy Federalnej (była to ustawa epizodyczna) 30 czerwca 1915 r. ${ }^{32}$

Ustawa o pieniądzu nadzwyczajnym, obok zawartych w niej rozwiązań wprowadzających większą elastyczność w podaży pieniądza, powołała do życia Krajową Komisję Monetarną (the National Monetary Commission), składającą się z dziewięciu senatorów i dziewięciu posłów Izby Reprezentantów, której przewodniczącym został republikański senator Nelson W. Aldrich, reprezentujący stan Rhode Island, zaś wiceprzewodniczącym - republikański poseł Edward B. Vreeland z Nowego Jorku. Głównym jej zadaniem było przeprowadzenie dogłębnych badań nad systemem pieniężnym i bankowym Stanów Zjednoczonych, analiza tkwiących w nim defektów i sformułowanie koniecznych zmian, a także wyciągnięcie wniosków z rozwoju bankowości centralnej w państwach europejskich i Japonii, po to, żeby na tej podstawie przedstawić dla Kongresu miarodajny raport z propozycjami odpowiednich reform prawnofinansowych oraz projekt ustawy o banku centralnym. Raport Komisji, nazywany również planem Aldricha (the Aldrich Plan), liczący 24 tomy, został zaprezentowany w Kongresie 9 stycznia 1912 r. Najistotniejsze zalecenia w nim zawarte dotyczyły:

- ustanowienia centralnego podmiotu prawnofinansowego, Krajowego Stowarzyszenia Rezerwy (the National Reserve Association) posiadającego piętnaście oddziałów, zdolnego do gromadzenia i utrzymywania rezerw bankowych we wspólnym funduszu oraz zapewnienia elastycznej waluty;

32 Por. M. Friedman, A. J. Schwartz, op. cit., s. 168-173 i zamieszczony tam przypis 57; J. Moen, E. Tallman, op. cit., s. 29-30; F. S. Mishkin, op. cit., s. 276; J. K. Galbraith, Pieniadz. Pochodzenie i losy, Państwowe Wydawnictwo Ekonomiczne, Warszawa 1982, s. 174-175. 
- utworzenia skoordynowanego systemu rozliczeń pieniężnych w skali kraju;

- powołania instytucji, która wraz z Departamentem Skarbu uczestniczyłaby w zarządzaniu długiem publicznym oraz rządowymi transakcjami międzynarodowymi ${ }^{33}$.

Projekt ustawy tworzącej Krajowe Stowarzyszenie Rezerwy, czyli nowy bank centralny Stanów Zjednoczonych, nie stał się jednak obowiązującym prawem po jego przedłożeniu Kongresowi. Stało się tak w głównej mierze dlatego, ponieważ Partia Republikańska utraciła większość nie tylko w obu izbach amerykańskiego parlamentu (podczas 62 kadencji Kongresu w latach 1912-1914 większość w Izbie Reprezentantów oraz w Senacie posiadała Partia Demokratyczna, która wykorzystała ją m.in. do zablokowania republikańskiego projektu ustawy o Krajowym Stowarzyszeniu Rezerwy), lecz na dodatek w 1912 r. republikański prezydent William $\mathrm{H}$. Taft przegrał wybory prezydenckie z kandydatem demokratycznym, Thomasem Woodrowem Wilsonem. Zastrzeżenia wysuwane przez demokratów wobec tego projektu dotyczyły przede wszystkim składu rad zarządzających piętnastu regionalnych banków centralnych, w których zasiadały osoby wybierane przez banki członkowskie $\mathrm{z}$ siedzibą $\mathrm{w}$ danym dystrykcie oraz formy nadzoru nad tą instytucją, która została powierzona dla Rady Dyrektorów (the Board of Directors) w Waszyngtonie, składającej się z gubernatora mianowanego przez prezydenta Stanów Zjednoczonych oraz 45 członków, w większości bankierów ze Wschodniego Wybrzeża. Nawiasem mówiąc, obawy polityków demokratycznych co do przejęcia kontroli nad nowym bankiem centralnym przez sfery Wall Street nie okazały się konfabulacją, lecz zostały potwierdzone w styczniu 1913 r. w oficjalnym sprawozdaniu specjalnej Podkomisji ds. Bankowości i Pieniądza Izby Reprezentantów, kierowanej przez Arsene Pujo, a faktycznie przez Samuela Untermyera, która od maja 1912 r. prowadziła śledztwo w sprawie zbadania oddziaływania elity nowojorskiego sektora bankowo-finansowego na konstytucyjne organy federalne w celu uchwalenia projektu ustawy o Krajowym Stowarzyszeniu Rezerwy w kształcie zapewniającym dominację tej grupy nacisku nad nowym bankiem centralnym. Dzięki temu oświadczeniu światło dzienne ujrzał również tryb pracy nad tą ustawą Krajowej Komisji Monetarnej. Mianowicie okazało się, że projekt ustawy o banku centralnym nie był oryginalnym dziełem Komisji, lecz został przedłożony senatorowi Aldrichowi przez Paula M. Warburga, bankiera inwestycyjnego z Wall Street, który nie był jej członkiem, podczas ściśle tajnej narady przedstawicieli największych rekinów finansowych USA w luksusowym kurorcie na archipelagu Jekyll's Island (okolice wybrzeży Brunszwiku, stan Georgia) w 1910 r. Tak więc projekt ustawy

33 Por. G. B. Tindall, D. E. Shi, op. cit., s. 925; W. Baka, Bankowość centralna..., s. 262; The Fed Today..., s. 1. 
o Krajowym Stowarzyszeniu Rezerwy był jedynie zmodyfikowaną wersją Zjednoczonego Banku Rezerw (the United Reserve Bank) autorstwa P. Warburga. Rewelacje te nie doprowadziły jednak ani do upadku idei powołania banku centralnego, ani nawet do zatrzymania prac ustawodawczych w komisjach Kongresu, ponieważ zdecydowana większość parlamentarzystów, w tym prezydent elekt T. W. Wilson, pozostawała zwolennikami ustanowienia naczelnego podmiotu prawnofinansowego. Mimo to raport „komisji Pujo” (Pujo committee) potwierdzający istnienie nieformalnego „Trustu Finansowego” (Money Trust), zorganizowanego przez J. P. Morgana i J. D. Rockefellera, wywołał poważny rezonans w szeregach Partii Demokratycznej, który przekształcił się w polaryzację stanowiska demokratów na dwie wyraźne frakcje posiadające różne poglądy na organizację i sposób nadzoru nad federalnym bankiem centralnym. Ostateczny kompromis pomiędzy tymi dwoma frakcjami zostanie zawarty dzięki osobistej mediacji prezydenta Wilsona i będzie odzwierciedlony w ustawie o Systemie Rezerwy Federalnej ${ }^{34}$.

Zwycięstwo Partii Demokratycznej w wyborach do obu izb Kongresu spowodowało rozwiązanie Krajowej Komisji Monetarnej oraz przyznanie jej kompetencji dla Komisji Izby Reprezentantów ds. Bankowości i Pieniądza (the House Committee on Banking and Currency), na której czele stanął demokratyczny poseł Carter Glass (analogiczna komisja w Senacie została utworzona dopiero w 1913 r.). Pomimo odrzucenia projektu ustawy o Krajowym Stowarzyszeniu Rezerwy przez parlament, Carter Glass postanowił wykorzystać go jako punkt wyjścia do opracowania nowej ustawy o banku centralnym, co spotkało się z aprobatą pozostałych członków Komisji. Decyzja ta wynikała z logicznego przeświadczenia, że skoro normatywna część planu Aldricha została tak entuzjastycznie przyjęta przez elitę finansową Nowego Jorku, ustawa o nowym banku centralnym nieuwzględniająca interesów tej części społeczeństwa może nie uzyskać wystarczającego poparcia, aby móc skutecznie funkcjonować. Pogląd taki podzielał również prezydent elekt i jego najbliżsi doradcy ekonomiczni. Zarazem jednak Carter Glass zdawał sobie sprawę z tego, że warunkiem sprzyjającym trwałości nowej ustawy o banku centralnym jest jej jak najszybsze uchwalenie. Dlatego też już 26 grudnia 1912 r., na kilka miesięcy przed objęciem urzędowania przez T. W. Wilsona, spotkał się w tej sprawie z prezydentem elektem w jego prywatnym mieszkaniu. W spotkaniu tym uczestniczył jeszcze Henry Parker

34 Por. R. T. Johnson, op. cit., s. 17-21; J. Moen, E. Tallman, op. cit., s. 28-34; E. Flaherty, op. cit., s. 14-15; M. Whitehouse, Paul Warburg's Crusade to Establish a Central Bank in the United States, tekst zaczerpnięty został z oficjalnej strony internetowej Regionalnego Banku Rezerwy Federalnej w Minneapolis pod adresem: http://www.minneapolisfed.org/pubs/region/89-05/REG895D.cfm, s. 1-10; P. M. Warburg, The Federal Reserve System. Its Origin and Growth, vol. 2, Addresses and Essays 1907-1924, Wyd. MacMillan Company, New York 1930, s. 117-161; J. K. Galbraith, op. cit., s. 175-177; M. A. Jones, op. cit., s. 441. 
Willis, ekspert Komisji ds. Bankowości i Pieniądza. Wilson zgodził się z poglądem gości, że instytucja ta powinna mieć strukturę zdecentralizowaną, złożoną nie mniej niż z ośmiu i nie więcej niż dwunastu regionalnych banków centralnych, uprawnionych do samodzielnego kształtowania wysokości stopy dyskontowej (co miało zapewnić elastyczne dostosowanie podaży weksli bankowych na regionalny rynek w celu zrównoważenia popytu na pieniądz), ale postawił warunek, aby nadzór nad tą instytucją sprawowany był przez organ centralny, a mianowicie Radę Rezerwy Federalnej, składającą się z osób mianowanych przez głowę państwa. Intencją prezydenta Wilsona było, aby System Rezerwy Federalnej, taka nazwa została bowiem przyjęta na oznaczenie trzeciego banku centralnego Stanów Zjednoczonych, otrzymał prywatno-publiczną organizację, w której Regionalne Banki Rezerwy Federalnej pozostałyby własnością banków handlowych, natomiast Rada Rezerwy Federalnej stałaby się agencją rządu federalnego, złożoną - co ustalono później, już w toku prac ustawodawczych z siedmiu osób, pięciu członków mianowanych przez prezydenta oraz sekretarza skarbu i kontrolera obiegu, którzy wchodziliby doń z urzędu. Dopowiedzieć należy, że ustalenia te zostały później uzupełnione o definitywne wykluczenie przedstawicieli bankierów z Rady Rezerwy Federalnej oraz przyznanie temu organowi prawa podmiotowego wyboru części składu Rady Dyrektorów Banków Rezerwy Federalnej i mianowania jej prezydenta (przewodniczącego Rady Dyrektorów). W ten sposób prawodawca starał się wzmocnić niezależność banku centralnego od sektora bankowego i sfery Wall Street, a jednocześnie uzyskać poparcie dla projektu ustawy grupy radykalnych agrarystów, której liderem był sekretarz stanu, William Jennings Bryan, a należał do niej m.in. Robert Latham Owen, przewodniczący Senackiej Komisji ds. Bankowości i Pieniądza. Ustępstwem z kolei na rzecz sektora bankowego była rezygnacja prezydenta z całkowitej kontroli rządu nad Systemem Rezerwy Federalnej. W praktyce oznaczało to, że nowy bank centralny otrzymał dość szeroki zakres niezależności, przejawiający się m.in. tym, że administracja nie mogła zaciągać w nim pożyczek na sfinansowanie wydatków budżetowych. Przyjęcie kompromisowych rozwiązań było zresztą konieczne, aby projekt ustawy uzyskał aprobatę większości w obu izbach. Ponadto twórcom ustawy o Rezerwie Federalnej chodziło $\mathrm{o}$ to, żeby instytucja ta zespalała interesy państwa $\mathrm{z}$ interesami kół gospodarczych i finansowych oraz interesami rolnictwa, pracowników i konsumentów. Aby nie dopuścić do zdobycia dominacji w systemie przez żadną grupę nacisku, zgodnie z uświęconą amerykańską tradycją, Kongres dołączył do niej jeszcze rozbudowany system „hamulców i równoważników” (checks \& balances) oraz opracował szczegółowy tryb powoływania najważniejszych funkcjonariuszy banku centralnego. Poprawki wniesione przez Komisje ds. Bankowości i Pieniądza Izby Reprezentantów i Senatu nie naruszały jednak zasadniczych postanowień projektu ustawy zaprezentowanej Kongresowi przez prezydenta Wilsona 23 czerwca 1913 r. Zaznaczyć przy tym trzeba, że omawiany projekt ustawy 
o Rezerwie Federalnej stanowił w istocie rzeczy relatywnie niewielką modyfikację projektu ustawy o Krajowym Stowarzyszeniu Rezerwy, uwzględniającym $\mathrm{w}$ treści poszczególnych przepisów postulaty wysuwane przez prezydenta Wilsona i niektóre propozycje sekretarza stanu, Bryana. Poparcie tego ostatniego było bowiem konieczne, aby ustawa o Rezerwie Federalnej uzyskała aprobatę na Kapitolu.

Złożenie projektu ustawy o Systemie Rezerwy Federalnej, przygotowanej przez H. P. Willisa, w obu Komisjach ds. Bankowości i Pieniądza, zostało poprzedzone specjalnym orędziem prezydenta Wilsona, wygłoszonym 23 czerwca $1913 \mathrm{r}$. na połączonej sesji Izby Reprezentantów i Senatu. Prezydent przedstawił w nim program reformy bankowo-walutowej, jej cele i przesłanki, a także zachęcał do udzielenia poparcia dla projektu ustawy. Rezonans prezydenckiego przemówienia był tak duży, że skłonił wielu przedstawicieli agrarnego skrzydła Partii Demokratycznej zasiadających w Kongresie do wyrażenia zgody na ustawę o banku centralnym, a ponadto nieoczekiwanie przyczynił się do zawarcia dwa dni później kompromisu między głównymi aktorami krucjaty na rzecz ustanowienia federalnego banku centralnego oraz przedstawicielami Amerykańskiego Stowarzyszenia Bankowców (the American Banking Association). Pojawienie się czterech najważniejszych członków Amerykańskiego Stowarzyszenia Bankowców na spotkaniu z prezydentem Wilsonem, kongresmenami Glassem i Owenem oraz Sekretarzem Skarbu, McAdoo, które odbyło się 25 czerwca, było starannie zaplanowaną formą wywarcia bezpośredniego nacisku na głowę państwa w celu przywrócenia pod obrady Kongresu ustawy o Krajowym Stowarzyszeniu Rezerwy w kształcie opracowanym przez Krajową Komisję Monetarną. Prezydent jednak stanowczo odmówił spełnienia tego żądania, natomiast zgodził się na uzupełnienie Systemu Rezerwy Federalnej o nowy organ, a mianowicie Federalny Zespół Doradczy (the Federal Advisory Council), składający się z przedstawicieli sektora bankowego, który miał pełnić funkcję łącznika (liaison) między Bankami Rezerwy Federalnej a Radą Rezerwy Federalnej w Waszyngtonie. Ponadto Wilson oraz pozostali twórcy ustawy o Systemie Rezerwy Federalnej zgodzili się przyznać większe uprawnienia dla Regionalnych Banków Rezerwy Federalnej w zakresie kształtowania wysokości stopy dyskontowej, co było tożsame z osłabieniem uprawnień w tym względzie organu centralnego, Rady Rezerwy Federalnej. Wreszcie ostatnim wymiernym skutkiem tego spotkania było udzielenie przez decydentów politycznych zgody na stopniowe - a nie natychmiastowe zastąpienie banknotów emitowanych przez banki narodowe nowym środkiem płatniczym banku centralnego, czyli banknotami Rezerwy Federalnej. W rezultacie stosownie zmieniony projekt ustawy o nowym banku centralnym trafił pod obrady obu komisji ds. Bankowości i Pieniądza 26 czerwca. Chociaż zawierał wiele kompromisowych rozwiązań, a patronat nad nim przejął osobiście prezydent Stanów Zjednoczonych, to jednak jego uchwalenie przeciągało się, ponieważ mniejszość republikańska była mu zdecydowanie przeciwna, a ponadto 
niektórzy politycy Partii Demokratycznej zasiadający w Izbie Reprezentantów wyłamali się z „dżentelmeńskiej umowy” prezydenta i sekretarza stanu, domagając się uprzedniego zniszczenia „Trustu Finansowego” i do tego czasu zawieszenia prac legislacyjnych nad tym projektem. Nie bez znaczenia było również dołączenie banków narodowych i sektora Domów Rozrachunkowych (liczącego 191 podmiotów na terenie całego kraju) do sojuszu republikanów z kołami Wall Street, mającego na celu blokowanie prac ustawodawczych nad ustawą o Rezerwie Federalnej, a w perspektywie - licząc na porażkę demokratów w nadchodzących wyborach przynajmniej do jednej Izby Kongresu - przywrócenie projektu ustawy o Krajowym Stowarzyszeniu Rezerwy. Na szczęście i tym razem osobiste spotkanie prezydenta Wilsona z czołowymi politykami Partii Demokratycznej z „frakcji Henry'ego”, przeciwnej ustanowieniu jakiegokolwiek banku centralnego, doprowadziło do zdobycia większości w niższej izbie parlamentu przez zwolenników uchwalenia the Federal Reserve Act ${ }^{35}$.

Ustawa o Systemie Rezerwy Federalnej została uchwalona przez Izbę Reprezentantów 18 września 1913 r. stosunkiem głosów 287 do 85. Należy przy tym zauważyć, że jedynie trzech posłów Partii Demokratycznej opowiedziało się przeciwko omawianej ustawie. Tak wyraźne poparcie dla projektu aktu normatywnego o Trzecim Banku Stanów Zjednoczonych świadczyło zwłaszcza o sukcesie polityki prezydenta T. W. Wilsona oraz skuteczności jego argumentów. Przeprowadzenie ustawy przez Izbę Reprezentantów nie gwarantowało jednak powodzenia w Senacie Stanów Zjednoczonych, o czym zresztą głowa państwa oraz pozostali twórcy tej ustawy doskonale zdawali sobie sprawę. Niepewność była tym większa, że przewodniczący senackiej Komisji ds. Bankowości i Pieniądza, Robert L. Owen, okazał się nie być całkowicie przekonany do przedstawionego projektu prawnofinansowego, a poza tym opozycja wobec niego wydawała się być relatywnie o wiele silniejsza w Senacie, aniżeli w Izbie Reprezentantów. Odzwierciedleniem sceptycznego podejścia senatora Owena był jego publiczny atak na podstawowe cechy struktury banku centralnego, a mianowicie na zasadę regionalizacji Banków Rezerwy Federalnej oraz przymusowe członkostwo banków narodowych w systemie. Zarzuty te spowodowały jednak niezwłoczną reakcję prezydenta Wilsona, co zakończyło się publicznym odwołaniem przez senatora postawionych zastrzeżeń. Mimo to jego niezdecydowanie i wyrażane publicznie zastrzeżenia nie pozostały bez echa, lecz przyczyniły się do tego, że większość senatorów zasiadających w Komisji ds. Bankowości i Pieniądza (w której prezydent Wilson posiadał stosunkowo mniejsze poparcie aniżeli w Senacie) zajęła nieprzychylne stanowisko wobec proponowanej reformy. Co

35 Por. R. T. Johnson, op. cit., s. 22-30; W. Baka: Bankowość centralna..., s. 262; F. S. Mishkin, op. cit., s. 493; Federal Reserve Act, tekst został zaczerpnięty ze strony internetowej pod adresem: http:// en.wikipedia.org/wiki/Federal_Reserve_Act, s. 1-2. 
gorsza, trzech z siedmiu demokratycznych członków tej Komisji zdecydowało się nie tylko nie popierać omawianego projektu ustawy, ale przyłączyć się do mniejszości republikańskiej, aby uniemożliwić jego uchwalenie. Senatorowie ci otrzymali też wsparcie ze strony Amerykańskiego Stowarzyszenia Bankowców. Aby przełamać zaistniały impas, prezydent Wilson postanowił zastosować taką samą metodę postępowania, która tak znakomicie sprawdziła się podczas „rebelii frakcji Henry'ego" w Izbie Reprezentantów, a mianowicie osobiste konsultacje z poszczególnymi senatorami w Białym Domu. Jednakże tym razem autorytet i argumenty głowy państwa nie wystarczyły do tego, aby zapewnić większość w Komisji ds. Bankowości i Pieniądza dla omawianego projektu ustawy. Na dodatek w październiku 1913 r. Frank A. Vanderlip, prezes zarządu National City Bank, jednego z największych nowojorskich banków (oraz prawnego poprzednika współcześnie istniejącego Citibank), zaprezentował na jej posiedzeniu alternatywny wobec Systemu Rezerwy Federalnej plan reform prawnofinansowych, którego głównym założeniem miało być utworzenie Centralnego Federalnego Banku Rezerwy (the Central Federal Reserve Bank) z główną siedzibą w Nowym Jorku. Kapitał akcyjny tej instytucji miał należeć do narodu, rządu federalnego oraz banków narodowych. Podstawowym jego zadaniem miała być emisja pieniądza do wysokości posiadanego kapitału akcyjnego. Nadzór i kontrola nad tą instytucją miała należeć całkowicie do rządu federalnego. Propozycja ustawodawcza F. A. Vanderlipa (the Vanderlip Plan), choć była normatywną odpowiedzią na wysuwane roszczenia radykalnych agrarystów oraz przedstawicieli sektora bankowego (w tym Wall Street), w istocie rzeczy była zawoalowanym sposobem obliczonym na storpedowanie ustawy Glassa - Willisa w Senacie. Mimo to już po kilku godzinach od jej ogłoszenia ośmiu z dwunastu członków tej komisji zdecydowało się na wspieranie propozycji Vanderlipa. W odpowiedzi na ten stan rzeczy prezydent Wilson wystąpił z oficjalną krytyką planu Vanderlipa, co w połączeniu z olbrzymią popularnością głowy państwa w społeczeństwie amerykańskim i presją administracji na izbę wyższą Kongresu zadecydowało w końcu o skierowaniu zarówno ustawy o Systemie Rezerwy Federalnej, jak również ustawy o Centralnym Federalnym Banku Rezerwy, pod głosowanie w Senacie. Rozstrzygające głosowanie w tej materii odbyło się w izbie wyższej 19 grudnia 1913 r. Projekt ustawy o Systemie Rezerwy Federalnej uzyskał delikatną przewagę nad zmodyfikowaną wersją „ustawy Vanderlipa”; został zaakceptowany większością zaledwie 3 głosów, 44 do 41. Następnie, kilka godzin później, Senat USA uchwalił ustawę o Systemie Rezerwy Federalnej stosunkiem głosów 54 do $34^{36}$.

Uchwalenie ustawy o Systemie Rezerwy Federalnej przez Izbę Reprezentantów i Senat Kongresu Stanów Zjednoczonych nie oznaczało automatyczne-

36 Por. R. T. Johnson, op. cit., s. 31-34. 
go przedstawienia tej ustawy do podpisu prezydentowi USA. Powodem tego były subtelne różnice występujące $\mathrm{w}$ treści normatywnej ustawy zaaprobowanej $\mathrm{w}$ oddzielnym głosowaniu przez obie Izby Parlamentu ${ }^{37}$. Unifikacja tej ustawy nastąpiła na posiedzeniu Połączona Komisja Izby Reprezentantów i Senatu ds. Bankowości i Pieniądza (the House and Senate Banking and Currency Committee). Przewodniczącym połączonych komisji został poseł Carter Glass, a jego zastępcą senator Robert Owen. W przeciwieństwie do wcześniejszego długotrwałego procesu legislacyjnego, ujednolicenie ustawy o Rezerwie Federalnej zajęło tylko dwa dni, po czym trafiła ona ponownie pod obrady obu izb Kongresu w celu jej ponownego uchwalenia. 22 grudnia 1913 r. Izba Reprezentantów ostatecznie uchwaliła ustawę o Systemie Rezerwy Federalnej bezwzględną większością 298 głosów za, 60 głosach przeciwnych oraz 76 wstrzymujących się. Z kolei Senat przyjął omawianą ustawę w dniu następnym, czyli 23 grudnia 1913 r., także bezwzględną większością głosów 43 senatorów za, przy 25 głosach przeciwnych oraz 27 wstrzymujących się. Paradoksem było, że w obu przypadkach demokraci - tradycyjni przeciwnicy banku centralnego, głosowali za jej przyjęciem, natomiast republikanie - orędownicy bankowości centralnej, byli jej przeciwni ${ }^{38}$.

Ustawa o Systemie Rezerwy Federalnej, nazywana również (od nazwiska jej głównych sponsorów w Izbie Reprezentantów i Senacie), ustawą Glassa - Owena, po zaaprobowaniu przez władzę ustawodawczą Stanów Zjednoczonych trafiła na biurko w Gabinecie Owalnym Białego Domu. 23 grudnia 1913 r. prezydent Wilson w otoczeniu najbliższych doradców politycznych, a wśród nich m.in. sekretarza skarbu Williama Gibbsa McAddo i Cartera Glassa, używając złotego pióra, podpisał ustawę o Systemie Rezerwy Federalnej o godzinie $18.02^{39}$. Po dokonaniu tej czynności prezydent powiedział: „Nie mogę zdradzić jak głębokie uczucie wdzięczności odczuwam, ale jestem przekonany, że mój udział w sfinalizowaniu tej pracy przyniesie trwały pożytek dla działalności gospodarczej w naszym państwie" 40 .

37 Tytułem przykładu można nadmienić, że projekt ustawy o Systemie Rezerwy Federalnej przyjęty w Izbie Reprezentantów przewidywał utworzenie przynajmniej 12 Regionalnych Banków Rezerwy Federalnej, natomiast wersja tej ustawy uchwalona przez Senat stanowiła, że liczba tych Banków nie może być niższa od ośmiu ani przekraczać dwunastu. Chociaż Połączona Komisja Izby Reprezentantów i Senatu ds. Bankowości i Pieniądza zgodziła się na wersję zaaprobowaną przez Senat USA, to jednak w większości innych przypadków przeważyło stanowisko Izby Reprezentantów, por. R. T. Johnson, op. cit., s. 34 .

38 Por. ibidem; E. Flaherty, op. cit., s. 15; Federal Reserve Act..., s. 2.

39 Por. R. T. Johnson, op. cit., s. 5; Overview of the Federal Reserve System, tekst zaczerpnięty został z oficjalnej strony Rady Gubernatorów Rezerwy Federalnej, dostępnej pod adresem: www.federalreserve.gov/pf/pdf/frspfl.pdf, s. 2.

40 Cyt. za: R. T. Johnson, op. cit., s. 34. 
9. Reasumując, utworzenie istniejącego do dnia dzisiejszego, trzeciego w historii Stanów Zjednoczonych, narodowego banku centralnego nie przyczyniło się ani do wygładzenia amplitudy wahań cyklu koniunkturalnego, trapiącego gospodarkę amerykańską od 1819 r., ani do skutecznego przeciwdziałania zjawiskom inflacyjnym albo deflacyjnym. W szczególności należy mieć na uwadze dopuszczenie do dużej ogólnej depresji gospodarczej w Stanach Zjednoczonych w latach 1929-1933, zastoju stagflacyjnego dekady lat siedemdziesiątych, zakończonego dopiero „eksperymentem monetarystycznym” Paula Volckera ${ }^{41}$, a przede wszystkim wystąpieniem współczesnego kryzysu finansowego, którego długość, skala i głębokość podważa adekwatność dotychczas wykorzystywanych mechanizmów stabilizacji przebiegu wewnętrznej koniunktury ${ }^{42}$. Należy przy tym skonstatować, iż w świetle aktualnego stanu wiedzy wydaje się, iż główna odpowiedzialność za pojawienie się wymienionych zaburzeń gospodarki leży po stronie nieroztropnej polityki finansowej tak administracji, jak i banku centralnego. Podtrzymywanie za wszelką cenę wzrostu gospodarczego, a zatem i wysokiej stopy zatrudnienia, za pośrednictwem ekspansywnej polityki fiskalnej (zwiększanie deficytu budżetowego) przy jednoczesnym powrocie do procyklicznej polityki pieniężnej - przejawiającej się utrzymywaniem niskich stóp procentowych, które samoistnie warunkują większą produkcję i niskie bezrobocie - prowadziło do pogłębiania się stanów nierównowagi w gospodarce, a zwłaszcza do spekulacyjnego wzrostu cen indeksów giełdowych ${ }^{43}$. Ten ostatni czynnik zasługuje na szczególną uwagę, ponieważ wzrost wyceny spółek publicznych ponad przyrost Produktu Krajowego Brutto odbywa się zazwyczaj kosztem „wypychania" inwestycji w sferę realną, w istocie więc jest to wzrost sztuczny, wzrost tylko na papierze. Poza tym jest to czynnik wybitnie inflacjogenny (kredyty na zakup akcji). W tym kontekście zasadniczym błędem był brak akceptacji jeśli chodzi o pojawiające się okresowo spowolnienia gospodarcze, na które można było dość łatwo oddziaływać $c^{44}$. Zamiast tego w społeczeństwie amerykańskim jako takim, a wśród rekinów finansowych w szczególności, narastało przeświadczenie, że prosperity będzie trwało nieprzerwanie długo, gdyż wyłączna dbałość władz monetarnych i Departamentu Skarbu o utrzymywanie wartości wymiennej waluty narodowej na relatywnie niskim poziomie, wobec tak sprzyjających okoliczności jak bankructwo systemu komunistycznego oraz konsensus waszyngtoński,

41 Por. E. Flaherty, op. cit., s. 15.

42 Por. wywiad z Przewodniczącym Rady Gubernatorów Systemu Rezerwy Federalnej, Benem Bernanke: Too big to fail is one of the biggest problems we face in this country, „Time”, January 2010, tekst został zaczerpnięty ze strony internetowej dostępnej pod adresem: http://www.time.com/time/ specials/packages/article/0,28804,1946375_194725100.html, s. 1-3.

43 Por. J. E. Stiglitz, Szalone lata dziewięćdziesiąte. Nowa historia najświetniejszej dekady w dziejach świata, Wydawnictwo Naukowe PWN, Warszawa 2006, s. 60 i 96-97.

44 Por. A. Wojtyna, Szkice o polityce pieniężnej, Polskie Wydawnictwo Ekonomiczne, Warszawa 2004, s. 11. 
będzie samoistnie podtrzymywało eksport jako katalizator odgrywający główną rolę w podtrzymywaniu aktywności gospodarczej. Tymczasem doświadczenia wielu innych państw pokazały, że kryzys finansowy może wystąpić nawet wówczas, gdy pod adresem prowadzonej polityki ekonomicznej trudno jest sformułować poważniejsze zarzuty (w każdym razie ex ante) ${ }^{45}$. Tak więc, chociaż ustanowienie Systemu Rezerwy Federalnej nie doprowadziło do wyeliminowania kryzysów finansowych lub recesji z rozwoju gospodarczego, to należy pamiętać, iż główną zasługą tego podmiotu prawnofinansowego jest gwarantowanie wypłacalności finansowej administracji oraz federalnych programów ochrony zdrowia i zabezpieczenia społecznego ${ }^{46}$.

10. Słowem, monopol emisji pieniądza gotówkowego, przyznany Systemowi Rezerwy Federalnej na podstawie artykułu 16 ustawy (przy poprzedniej wielości pieniędzy emitowanych przez banki narodowe) oraz stworzenie elastycznego mechanizmu rezerw banków komercyjnych, co umożliwiło sprawną wypłatę wkładów na żądanie ich posiadaczy i co sprawiło, że bankowy wkład na rachunku bieżącym (od 2008 r. oprocentowanym) stał się pieniądzem transakcyjnym, słusznie należy uznać za największy sukces jego twórców ${ }^{47}$.

Brzmienie artykułu 16 ustawy zatytułowanego „Emisja pieniądza” (Note Issues) nie pozostawia zatem najmniejszej wątpliwości, że pieniądz banku centralnego (mimo że obecnie oderwany od wartości materiału, z jakiego został wykonany) stanowi pieniądz wielkiej mocy, posiadający największą płynność i spełniający funkcje środka ostatecznej zapłaty ${ }^{48}$. Wskazuje na to expressis verbis norma prawna zawarta w zdaniu drugim artykułu 16 ustęp 1, która stanowi, iż „wspomniane banknoty będąc obligacjami Stanów Zjednoczonych będą honorowane przez wszystkie banki narodowe, członkowskie i Banki Rezerwy Federalnej jako zapłata za wszelkie zobowiązania podatkowe, celne oraz inne należności publiczne" ${ }^{\prime 9}$. To swoiste upoważnienie ustawowe umożliwia zarazem kształtowanie za pomocą strumienia pieniądza korzystnych okoliczności do realizacji różnych, często wzajemnie sprzecznych, strategicznych wyznaczników polityki pieniężnej w postaci pełnego zatrudnienia, stabilności cen i kursu wa-

45 Ibidem, s. 15.

46 Por. N. Ferguson: Kolos. Cena amerykańskiego imperium, Sprawy Polityczne, Warszawa 2010, s. 401-452; D. C. Wheelock, op. cit., s. 1.

47 Por. J. Zajda, Systemy bankowe w gospodarce kapitalistycznej, s. 175; The Federal Reserve Today. 16th Edition, tekst został zaczerpnięty ze strony Regionalnego Banku Rezerwy Federalnej w Richmond, dostępnej pod adresem: http://richmondfed.org/publications/education/federal_reserve_today/ frtoday.pdf, s. 18.

48 Por. H. Zadora, Finanse i bankowość w gospodarce światowej, Wydawnictwo Politechniki Śląskiej, Gliwice 2004, s. 53-55.

49 Tłumaczenie własne na podstawie Federal Reserve Act, której tekst został zaczerpnięty z oficjalnej strony internetowej Rady Gubernatorów Systemu Rezerwy Federalnej, dostępnej pod adresem: http://www.federalreserve.gov/generalinfo/fract/sect16.html, s. 1. 
lutowego, zachowywanie integralności instytucji depozytowych i niedopuszczanie do pojawienia się kryzysów finansowych, za pośrednictwem terminowego dyskontowania papierów wartościowych Skarbu Państwa, publicznych funduszy ochrony zdrowia Medicare i Medicaid, weksli dłużnych wystawianych przez poszczególne stany i hrabstwa oraz obligacji prywatnych (w tym wprowadzanych do obrotu przez największe banki i konglomeraty finansowe) ${ }^{50}$. Dzięki temu System Rezerwy Federalnej niejako „na bieżąco” i w aspekcie długookresowym wypełnia powierzoną mu w preambule do ustawy o Rezerwie Federalnej misję, do której został on powołany. Preambuła do ustawy o Rezerwie Federalnej, niezmieniona od 1913 r., stanowi, iż ustawa o Rezerwie Federalnej została uchwalona „po to, żeby zagwarantować utworzenie federalnych banków rezerwy w celu dostarczenia elastycznego pieniądza, zapewnienia środków do redyskontowania weksli handlowych oraz by ustanowić bardziej efektywny nadzór bankowy w Stanach Zjednoczonych, oraz dla innych celów" ${ }^{51}$. Z uwagi zaś na jej normatywny charakter ${ }^{52}$ władze monetarne mogą uznawać za finalne cele polityki pieniężnej, również te jej uwarunkowania, które nie posiadają umocowania ustawowego ${ }^{53}$. Spośród nich najważniejszy jest cel w postaci utrzymania stabilności rynków finansowych. Głównym tego uzasadnieniem jest związek stabilności finansowej ze stabilnością cen, rynkowych stóp procentowych oraz pełnym zatrudnieniem. System Rezerwy Federalnej może zahamować panikę w stadium początkowym, reagując $\mathrm{w}$ odpowiednim czasie takim zwiększeniem podaży pieniądza rezerwowego, aby zaspokoić rosnący popyt na pieniądz gotówkowy oraz na rezerwy utrzymywane przez banki na ich rachunkach w banku centralnym. W tym celu System pełni funkcję pożyczkodawcy ostatniej instancji. Istotne znaczenie ma również sama deklaracja ze strony banku centralnego, że jest on gotów zapewnić systemowi bankowemu odpowiednią płynność. Deklaracja taka jest wiarygodna, zwłaszcza jeśli została publicznie wygłoszona przez członków jego organów zarządzających, ponieważ tylko bank centralny może stanowić ostateczne źródło pieniądza gotówkowego dla banków na wypłatę depozytów dla ich klientów. Dlatego monopol emisji pieniądza i wynikający z tego obowiązek zapewnienia gospodarce takiej ilości pieniądza, jaka niezbędna jest do sprawnej obsługi transakcji, budzi naturalne zainteresowanie władz monetarnych stabilnością systemu finansowego ${ }^{54}$.

50 Por. F. S. Mishkin, op. cit., s. 589; P. S. Nadler, Banki komercyjne w gospodarce, Biblioteka Menedżera i Bankowca, „Zarządzanie i Finanse”, Warszawa 1993, s. 30-37 i 59-67; The Federal Reserve Today..., s. $12-18$.

51 Tłumaczenie własne na podstawie Federal Reserve Act.

52 Por. J. P. Judd, G. D. Rudebusch, op. cit., s. 1.

53 Por. np. The Federal Reserve Today..., s. 15-18.

54 Por. O. Szczepańska, op. cit., s. 70-74. 